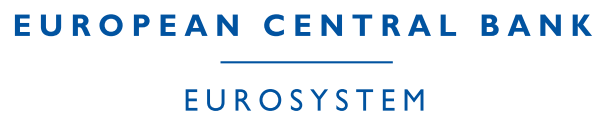

\title{
HISTORY, GRAVITY AND INTERNATIONAL FINANCE
}

\author{
Livia Chițu, \\ Barry Eichengreen \\ and Arnaud Mehl
}

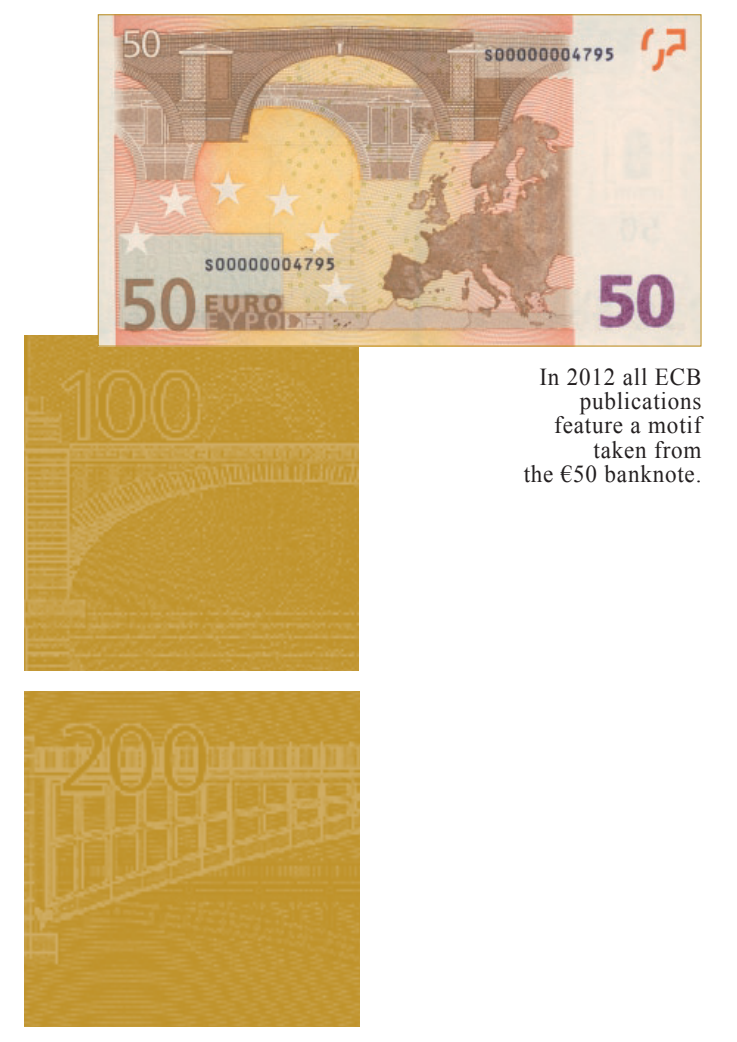

NOTE: This Working Paper should not be reported as representing the views of the European Central Bank (ECB). The views expressed are those of the authors and do not necessarily reflect those of the $E C B$. 


\section{Acknowledgements}

The authors are grateful to Nicolas Coeurdacier and Andy Rose for comments and suggestions and to Martin Evans, Roberto De Santis and Shang-Jin Wei for helpful discussions. The views expressed in this paper are those of the authors and do not necessarily reflect those of the ECB or the Eurosystem.

\section{Livia Chițu}

at European Central Bank, Kaiserstrasse 29, D-60311 Frankfurt am Main, Germany; e-mail: livia.chitu@ecb.europa.eu

\section{Barry Eichengreen}

at University of California, Berkeley, 603 Evans Hall, Berkeley, CA 94720, USA; e-mail: eichengr@econ.berkeley.edu

\section{Arnaud Mehl}

at European Central Bank, Kaiserstrasse 29, D-60311 Frankfurt am Main, Germany; e-mail: arnaud.mehl@ecb.europa.eu

\section{(C) European Central Bank, 2012}

\section{Address}

Kaiserstrasse 29, 60311 Frankfurt am Main, Germany

Postal address

Postfach 1603 19, 60066 Frankfurt am Main, Germany

\section{Telephone}

+496913440

\section{Internet}

http://www.ecb.europa.eu

\section{Fax}

+496913446000

All rights reserved.

ISSN 1725-2806 (online)

Any reproduction, publication and reprint in the form of a different publication, whether printed or produced electronically, in whole or in part, is permitted only with the explicit written authorisation of the ECB or the authors.

This paper can be downloaded without charge from http://www.ecb.europa.eu or from the Social Science Research Network electronic library at http://ssrn.com/abstract_id=2140781. 


\begin{abstract}
$\underline{\text { Abstract }}$
We analyze persistence in patterns of bilateral financial investment using data on US investors' holdings of foreign bonds. We document a "history effect" in which the pattern of holdings seven decades ago continues to influence holdings today. 10 to $15 \%$ of the cross-country variation in US investors' foreign bond holdings is explained by holdings 70 years ago, plausibly reflecting fixed costs of market entry and exit. This effect is twice as large for bonds denominated in currencies other than the dollar, suggesting the existence of even higher fixed costs of initiating US foreign investment in currencies other than the dollar. Our findings point to history and path dependence as key sources of financial market segmentation.
\end{abstract}

Key words: gravity model, international finance, geography of asset holdings, persistence, hysteresis, international role of the dollar

JEL classification: F30, N20 


\section{Non-technical summary}

Recent years have seen growing interest in the geography of international finance. In particular, a series of studies has used gravity models to analyse the direction and determinants of cross-border financial stocks and flows. In this approach, bilateral trade in assets is posited to increase with country size and to decline with transaction costs and information asymmetries, as captured by geographic distance and related variables.

This literature has focused all but entirely on recent decades. While this focus usefully highlights the progress of financial globalisation since the early 1990s, it is not capable of capturing longer-term historical forces that may also influence patterns of international investment.

It is this shortcoming that we address in this paper by showing that history plays a role in the geography of international finance. We estimate a gravity model of international investment using data on US investors' holdings of foreign bonds in 88 countries seven decades ago, a period on which we focus because of the existence of uniquely detailed data. We document a "history effect" in which US bilateral holdings 70 years ago help to explain the allocation of US holdings around the world today.

Past investment may influence current investment due to the existence of fixed costs. The theoretical and empirical literature on so-called "beachhead" or "hysteresis" effects has shown that transitory shocks resulting in market penetration can permanently impact patterns of trade if firms incur fixed costs when entering new markets but cannot easily recoup them if they subsequently wish to exit.

Intuition suggests that what is true of international trade is also true of international investment. Financial firms face fixed costs when seeking to market the foreign bonds of a country or countries to domestic investors. They also face fixed costs in order to gather intelligence on foreign markets and underwrite the bond issues of foreign borrowers. These fixed costs need not be large to have persistent effects on the geography of bilateral asset holdings. As suggested in the literature on endogenous learning, they only need to be different across countries. Lower initial fixed costs of investing in some countries may significantly tilt investment toward those countries; and this pattern may persist and be amplified over time through endogenous learning.

In this paper we use past holdings of a country's bonds as an indirect indicator of the fixed costs in question - of the fact that investors have sunk the costs of acquiring information about that class of bonds. We find evidence in our data that the "history effect" is statistically significant, robust and economically important even after controlling for the arguments of the standard gravity model. Our estimates suggest that a $1 \%$ increase in US holdings of foreign bonds in a country 70 years ago is associated with holdings of some $1 \%$ higher in the same country today. They also suggest that 10 to $15 \%$ of the cross-sectional variance of today's US holdings of foreign bonds is attributable to the effect of the holdings of 70 years ago. 
These findings are robust to including standard measures of informational frictions such as common language, legal origin, and past colonial status. They are robust to controlling for omitted variable bias with regional fixed effects. They are robust to outliers. They extend to other securities besides bonds. The causal interpretation of the effect is buttressed by the observation that it remains when one instruments lagged holdings with dummies that aim to capture the effects of the disintegration of the gold standard and of the sovereign defaults of the 1930s, which contributed to the growing segmentation of global financial markets during the Great Depression.

The "history effect" is also twice as large for foreign-currency-denominated bonds as for dollar bonds. As much as $30 \%$ of the worldwide allocation of US investors' foreign holdings of non-dollar bonds today can thus be explained by the pattern of such holdings seven decades ago. In the case of non-dollar bonds, investors have to learn not just about the foreign issuer but also about his or her currency; and they might also need adequate markets or institutions to hedge currency risk. This implies larger sunk costs and, in turn, a larger history effect.

The early literature on gravity in international finance found that the geographical component of cross-border financial flows and holdings is substantial that international financial markets are not frictionless but segmented by market size, informational asymmetries and familiarity effects. Subsequent studies established the importance of complementarities between trade in goods and trade in assets. In this paper we show that history also matters - that historical patterns persistently weigh on the geography of bilateral asset holdings.

These findings underscore the need for more analysis of the currency composition of countries' foreign assets and liabilities, along with their causes and effects. They also underscore how the role of the dollar as a global investment currency today is partly a legacy of this earlier era when it dethroned sterling as the leading international currency. 


\section{Introduction}

Recent years have seen growing interest in the geography of international finance. In particular, a series of studies has used gravity models to analyse the direction and determinants of cross-border financial stocks and flows. ${ }^{1}$ In this approach, bilateral trade in assets is posited to increase with country size and to decline with transaction costs and information asymmetries, as captured by geographic distance and related variables. $^{2}$

This literature has focused all but entirely on recent decades. ${ }^{3}$ While this focus usefully highlights the progress of financial globalisation since the early 1990s, it is not capable of capturing longer-term historical forces that may also influence patterns of international investment. ${ }^{4}$

It is this shortcoming that we address in our paper. We estimate a gravity model of international investment using data on US investors' holdings of foreign bonds in 88 countries seven decades ago. We test for a "history effect" through which the past holdings of US investors influence their current holdings. ${ }^{5}$

Why might past investment influence current investment? One answer is fixed costs. The theoretical and empirical literature on so-called beachhead or hysteresis effects (Baldwin, 1988; Dixit, 1989; Baldwin and Krugman, 1989) has shown that transitory shocks resulting in market penetration can permanently impact patterns of trade if firms incur fixed costs when entering new markets but cannot easily recoup them if they subsequently wish to exit. ${ }^{6}$ Intuition suggests that what is true of international trade is also true of international investment. Financial firms face fixed costs when seeking to market the foreign bonds of a country or countries to domestic

1 See e.g. Portes and Rey, 2005; Ahearne, Griever and Warnock, 2004; Eichengreen and Luengnaruemitchai, 2006; Aviat and Coeurdacier, 2007; Daude and Fratzscher, 2008; Lane and MilesiFerretti, 2008a and 2008b; De Santis and Gerard; 2009; Coeurdacier and Martin, 2009; Forbes, 2010; Okawa and van Wincoop, forthcoming.

2 Several papers (including Martin and Rey, 2004; Coeurdacier and Martin, 2009; and Okawa and van Wincoop, forthcoming) show how a simple and intuitive gravity equation can be derived from theory and taken to the data.

${ }^{3}$ See, however, Clemens and Williamson (2004) and Esteves (2011) for broadly similar analyses of earlier historical periods.

${ }^{4}$ It also tells us nothing about the generality (about the applicability over time) of the factors emphasized by the gravity model.

${ }^{5}$ In this respect our paper is closely related to Eichengreen and Irwin (1998), who focused on the role of history in the gravity of international trade in goods.

${ }^{6}$ For instance, it is observed that Japanese firms that entered US markets in the early 1980s when the dollar had significantly appreciated did not abandon their sunk investments when the dollar fell in the wake of the Plaza agreement of 1985. Once firms had invested in marketing, R\&D, reputation, distribution networks, etc., they found it profitable to remain in US markets even at a lower exchange rate. The dynamic effects of economies of scale and monopolistic competition in industries such as autos, computers, and aircraft, only compound the impact of sunk costs, but the latter can also lead to hysteresis in highly competitive sectors (Dixit, 1989). Dixit (1989, p. 207) assumes that "at any instant ... firms that are in the market act as price-takers", which in his view is a "sensible assumption in many industries even when sunk costs are important for each firm, agriculture, textiles, and many consumer electronics products, and even steel are cases in point", while for "other industries" "somewhat less competitive conduct would be more appropriate." Note that, stricto sensu, hysteresis warrants that a transitory shock has permanent effects. In our case, however, what is necessary is only that a transitory shock has highly persistent effects that are still perceptible after decades. 
investors. US banks had to sink the costs of setting up foreign branches in order to gather intelligence on foreign markets and underwrite the bond issues of foreign borrowers when the ban on foreign branching was lifted by the Federal Reserve Act of 1913. US investment banks had to sink the costs of setting up store-front brokerages and other marketing tools when seeking to sell those bonds to investors in the 1920s (Eichengreen, 1989). ${ }^{7}$ Not just the willingness of US investors to purchase foreign bonds but, arguably, the countries whose bonds they found attractive were affected by the costs sunk in earlier periods. ${ }^{8}$

Fixed costs need not be large to have persistent effects on the geography of bilateral asset holdings. They only to be different across countries. An example is the costs of asymmetric information, as analysed in the literature on endogenous learning. In Van Nieuwerburg and Veldkamp (2009)'s model, for instance, even a small informational advantage associated with domestic assets can cause significant home bias. The informational advantage reduces the perceived riskiness of domestic assets, which encourages investors to hold more of them. This in turn induces investors to learn even more about such assets, making them still more attractive. Endogenous learning thus amplifies the initially small information advantage. Analogously, lower initial fixed costs of investing in some countries may significant tilt investment toward those countries over time; moreover, this pattern may persist and be amplified over time by endogenous learning.

Ideally, one would have direct measures of these fixed costs, including differences in brokers' fees between domestic and foreign investments, differences in tax treatment, and policy-related costs (e.g. those associated with limits to foreign investment and capital controls). Unfortunately, no paper, as far as we know, has been able to provide a comprehensive measure of direct costs in investing in foreign assets, not even for the contemporary period, much less for earlier historical eras (Coeurdacier and Rey, 2011). It is thus necessary to make inferences about their importance from indirect evidence.

In this paper we use past holdings of a country's bonds as an indirect indicator of the fixed costs in question - of the fact that investors have sunk the costs of acquiring information about that class of bonds. We find that US holdings of the bonds of a country in 1943, a year on which we focus because of the existence of detailed data, significantly influence US holdings of foreign bonds of that country in 2010 even after controlling for other standard determinants. ${ }^{9}$ As much as $15 \%$ of the worldwide allocation of US investors' holdings today can be explained by holdings seven decades ago.

\footnotetext{
${ }^{7}$ In this respect, contemporaries noted that foreign bonds were sold to US savers by "intensive sales campaigns" in which "no sale was too small and no place too obscure to attract the salesman" and where "the sympathies of the foreign born were worked upon" (US Treasury, 1947, p. 39).

${ }^{8}$ But there is also the counterargument that subsequent events overwhelmed the influence of earlier investment patterns. An example is Cuba, a country with close economic links to the United States until 1959 and with which US investors had developed significant economic interests and held relatively large numbers of bonds. After the Cuban revolution, however, the new government expropriated foreign investors. This explains why US investors today hold negligible amounts of Cuban bonds, although they used to hold large ones in the past.

${ }^{9}$ Why we consider 1943 in particular will become evident momentarily.
} 
Moreover, this "history effect" is twice as large for foreign-currencydenominated bonds as for dollar bonds. As much as $30 \%$ of the worldwide allocation of US investors' holdings of non-dollar bonds today can thus be explained by the pattern of such holdings seven decades years ago. In the case of non-dollar bonds, investors have to learn not just about the foreign issuer but also about his or her currency; and they might also need adequate markets or institutions to hedge currency risk. This implies larger sunk costs and, in turn, a larger history effect.

Our finding that the impact of history on US foreign bond holdings depends on the currency denomination of those bonds strengthens a point made by Lane and Shambaugh about the need for more analysis of not just the currency composition of foreign assets and liabilities but also their determinants, about which "remarkably little [is] known" for most countries (Lane and Shambaugh, 2010, p. 518). We begin to fill this gap when it comes to one specific aspect of US foreign assets, namely foreign security holdings.

Section 2 presents the data used in our empirical analysis. Section 3 then sets out the methodology. Section 4 describes the key stylised facts, while Sections 5 and 6 present gravity model estimates for 2010 and 1943, respectively. Section 7 tests for the presence of the history effect. Section 8 reports our separate results for dollar- and foreign-currency-denominated bonds, after which Section 9 concludes.

\section{Data}

There is a long-standing interest in measuring international holdings of financial assets in and by the United States. The first systematic effort of which we are aware dates to 1853, when the US Department of Treasury carried out a survey of foreign holdings of US securities in response to Congressional concerns over the rising amounts of US debt held by foreigners (Griever and Warnock, 2001). Other surveys of foreign holdings of US financial assets followed in the 1930s (focusing on securities specifically) and early 1940s (covering all financial assets). ${ }^{10}$

We use a survey of US ownership of foreign assets conducted by the Treasury Department in 1943 as our source for estimates of US investors' past holdings of foreign bonds. We focus on this particular survey because it was unusually comprehensive and carefully executed and because, uniquely, it contains information on the currency composition of US foreign bond holdings.

The motivations for undertaking this survey were several. The authors note how it provided "much greatly needed information during the latter part of the military phases of the war" (US Treasury, 1947, p. 1). ${ }^{11}$ They observe further that the

\footnotetext{
${ }^{10}$ See the review in Lewis (1948).

${ }^{11}$ The survey was conducted under the lead of the US Treasury with inputs from the Department of State and Commerce, the Board of Governors of the Federal Reserve System, and received comments from representatives of the financial industry. The Census of American-owned assets in Foreign Countries on form TFR-500 was announced on 3 June 1943 through the issuance of Special Regulation No.1, under Executive Orders No. 8389 and No. 9193 (US Treasury, 1947, p. 5). Property interests as of 31 May 1943 by persons subject to the jurisdiction of the US were to be reported to the US Treasury by 31 August 1943.
} 
information gleaned through the survey might prove useful in subsequent peace negotiations and help US residents to obtain compensation for foreign assets confiscated or destroyed during wartime.

Treasury officials undertaking the survey believed that "the results were in general such as to cause confidence as to the degree of completeness and accuracy of the census." In introducing the findings in 1947, Treasury Secretary J. W. Snyder observed that the total foreign assets owned by the US on 31 May 1943, the date for which data were reported, in the amount of $\$ 13.5$ billion, "greatly exceeded expectations" (US Treasury, 1947, p. vii). Again this suggests that the survey in question was relatively comprehensive.

We extracted data on US investors' holdings of foreign bonds in 88 countries (see Annex A1 for a complete list) at market values (see US Treasury, 1947, Table 7 pp. 80-81). We also digitized data on foreign equity and total foreign security (i.e. bond and equity) holdings, which we further analyse below. Finally, for 41 countries, we also gathered information on US foreign holdings of dollar-denominated bonds (see Annex A1 for further details). ${ }^{12}$

For the recent period our source on the pattern of US foreign financial investment is the Report on US Portfolio Holdings of Foreign Securities (US Treasury et al., 2011). We use the latest survey currently available, of holdings as of 31 December 2010. Such surveys were launched in the 1990s, when US investments in foreign securities increased significantly. They have been conducted annually now for ten years. The results are believed to be of high quality given that the surveys collect information at the individual security level, reporting is mandatory, there are penalties for non-compliance, and these surveys are part of an internationally-coordinated effort under the auspices of the International Monetary Fund to improve the measurement of portfolio asset holdings (Ahearne et al. 2004; Forbes, 2010). We retrieved data on US investors' holdings of foreign long-term debt securities at market value (US Treasury et al., 2011, Table A6, p. 53).

The sample of countries is the same as for the 1943 data with a few exceptions. Some countries that existed then no longer exist today, and vice versa. In other cases, national boundaries have changed significantly. ${ }^{13}$ The 2010 counterparts of 1943 holdings for e.g. Czechoslovakia or Yugoslavia are calculated as the totals for the Czech Republic and Slovakia and for Bosnia, Croatia, Macedonia, Serbia and Montenegro, respectively. Danzig and Newfoundland, which were treated as independent entities in 1943, are included with Poland and Canada to allow for comparison with the 2010 data. Annex A3 provides the complete list of adjustments. ${ }^{14}$

\footnotetext{
12 The par value of US foreign holdings of dollar-denominated bonds reached almost \$2 billion in 1943. A substantial share of these bonds was in default, however, owing to the events of the 1930s; hence their market value was lower, at about $\$ 1.6$ billion, than their par value. Of these defaulted bonds, half were Latin American, a quarter were European (including bonds of the Axis nations), while most of the remainder were Canadian, Japanese and Chinese.

${ }^{13}$ In still other cases, names have changed; thus, what used to be known as British Malaya or British Honduras, are now known as Singapore or Belize, respectively.

${ }^{14}$ And correspondences between country names in 1943 and 2010.
} 
The total market value of US holdings of foreign securities issued by the countries in our sample reached almost $\$ 6.3$ trillion by the end of 2010. Of this amount, about $\$ 1.6$ trillion were holdings of foreign bonds.

\section{Empirical framework}

The first step in our analysis is to estimate a standard gravity model akin to the specification proposed in e.g. Coeurdacier and Martin (2009) and Okawa and van Wincoop (2012). The dependent variable is the logarithm of US investors' holdings of foreign bonds in 2010 or 1943 in country $j$, denoted $X$

$$
\log \left(X_{j}\right)=\alpha+\boldsymbol{\beta}_{\mathbf{J}}+\gamma\left(\frac{G D P_{j}}{G D P_{\text {world }}}\right)+\Phi \log \left(Z_{j}\right)+\varepsilon_{j}
$$

which we regress on a constant $\alpha$, a vector of regional effects $\boldsymbol{\beta}$ (with $\mathrm{J}=1 \ldots 7$ ); and country j's share in world GDP at 1990 prices in 1999-2008 and 1931-1941, respectively. ${ }^{15}$ To make the comparison of coefficient estimates over time as straightforward as possible, we employ GDP shares (from Maddison, 2010) rather than GDP itself as a measure of market size. ${ }^{16}$

$Z$ denotes international financial market frictions, for which we assume the functional form:

$$
Z_{j}=\text { Trade }_{j}^{\varphi_{1}} \text { Distance }{ }_{j}^{\varphi_{2}} \exp \left(\varphi_{3} \text { legal }+\varphi_{4} \text { comlang }+\varphi_{5} \text { colony }\right)
$$

where Trade is the sum of exports and imports from the US to country $j$; Distance is the distance in miles between Washington, D.C. and country j's city capital; legal is a dummy variable that equals 1 when the origin of country $j$ 's legal system is English common law (as indicated in La Porta, Lopez de Silanes and Shleifer, 2006); comlang is a dummy that equals 1 when English is the official language of country $j$ (as in Rose and Spiegel, 2004); and colony a dummy that equals 1 when country $j$ is either Cuba or the Philippines (the two former US colonies in our sample).

Okawa and van Wincoop (forthcoming, p. 2) stress that $Z$ should not contain variables that have "no theoretical justification for being there" (the example they give being asset-return correlations). All the variables included there are standard in the literature, which provides ample theoretical justification for their inclusion, with the possible exception of trade. Past studies have found that legal origin, common language and colonial relationships significantly affect geographical patterns of

\footnotetext{
${ }^{15}$ We consider 1999-2008 for the recent period because we lack data for 2009-10. For the earlier period, we are similarly forced to truncate the 1931-41 average where World War II results in the unavailability of data for some years for some countries.

${ }^{16}$ This allows us to have maximal data coverage (given that nominal GDP data, especially pre-1945, were not available for many countries of our sample).
} 
financial flows and holdings (see e.g. Aviat and Coeurdacier, 2007; Coeurdacier and Martin, 2009; Lane and Milesi-Ferreti, 2008a and 2008b; Forbes, 2010). These three variables aim to capture informational costs or asymmetries that go beyond closeness factors captured by geographic distance; they are sometimes described as capturing "familiarity" or "connectivity." We include trade on the grounds that commercial transactions are a source of intelligence useful for informing foreign investment decisions (Antras and Caballero, 2007); and the existence of trade links may make foreign investments more secure insofar as strategic default is deterred by the threat of commercial retaliation (Rose and Spiegel, 2004). In terms of empirical justification, Aviat and Coeurdacier (2007), Lane and Milesi-Ferreti (2008a) and (2008b), Coeurdacier and Martin (2009), Forbes (2010) and Coeurdacier and Rey (2011) report evidence that trade in goods is an important determinant of trade in assets.

Short-term disruptions affected longer-term patterns of trade in both periods. The outbreak of World War II disrupted trade in the early 1940s. The evaporation of trade financing and the collapse in global trade after the bankruptcy of Lehman Bros. in 2008/9 similarly disrupted patterns of trade. To prevent these disruptions from dominating our data, we measure Trade as decade-long averages of bilateral trade (exports and imports) with the US, averaging amounts from 1931 to 1940 and 2000 to 2010, respectively. ${ }^{17}$ Data on trade are taken from the IMF DOTS database for the current era and from the US Statistical Abstracts for the period prior to World War II.

We estimate Eq. (1) by ordinary least squares, reporting heteroskedastic-robust standard errors. Since there are observations for which US holdings in 2010 are zero but which still may contain information as to why low values of US investments are observed, we express the dependent variable as $\log (1+X) .{ }^{18}$ We then test for whether US investors' holdings in 1943 help predict 2010 holdings. To this end, we modify Eq. (1) to the form:

$$
\log \left(X_{j}^{2010}\right)=\alpha+\boldsymbol{\beta}_{\mathbf{J}}+\gamma\left(\frac{G D P_{j}^{2010}}{G D P_{\text {world }}^{2010}}\right)+\Phi \log \left(Z_{j}^{2010}\right)+\eta \log \left(X_{j}^{1943}\right)+\varepsilon_{j}
$$

where our null hypothesis is that $\eta=0$ (i.e. a rejection of the null is evidence in favour of the history effect).

Estimating Eqs. (1) and (2) raises a number of challenges. A first one is controlling for the endogeneity of bilateral trade. ${ }^{19}$ Following Aviat and Coeurdacier (2007) we instrument bilateral trade with transport costs, its square and the number of

\footnotetext{
${ }^{17}$ Consistent with our use of decade-long averages for country shares of global GDP. We also test the sensitivity of our results to other measures (see below).

${ }^{18}$ While for large values, $\log (1+X) \approx \log (X)$, we also specifically control for outliers using a robustto-outlier estimator in the robustness checks. The dependent variable is expressed in the same fashion for the regressions on 1943 data below.

${ }^{19}$ For instance, if information asymmetries exist, private agents may learn about each other by trading goods and this information may help facilitate trading in financial assets. Alternatively, in the model of Obstfeld and Rogoff (2000), trade costs induce a bias in investors' portfolios towards domestic securities and securities of their trading partners. Aviat and Coeurdacier (2007) and Coeurdacier and Martin (2009) emphasize this point.
} 
landlocked countries in the country pair. Shipping costs are plausibly correlated with trade in (material) goods but not trade in (immaterial) financial assets. ${ }^{20}$ Similarly, there is no obvious reason why landlockedness should affect financial transactions in the same manner that it affects trade in goods. We measure transport costs as the dollar price of shipping one kilogram of (non-valuable) goods by UPS from the US to the city capital of the 88 countries of our sample.

A second challenge is controlling for omitted variables. We may do this by including country source and destination effects, which also capture so-called "multilateral resistance" frictions, i.e. the fact that bilateral financial holdings depend on relative barriers, i.e. bilateral financial barriers relative to average barriers faced by both source and destination countries (see e.g. Anderson and van Wincoop, 2003; Coeurdacier and Martin, 2009; Okawa and van Wincoop, 2012).

But since we have only one source country, the US, and 88 destination countries, estimating destination-country effects is not feasible. ${ }^{21}$ We therefore include regional effects instead of destination country effects. ${ }^{22}$ We allocate countries in eight regions (Asia, Central America, Europe, North America, Oceania South America, West Indies; with Africa treated as the base region) following the classification used in US Treasury (1947); see Annex A1.

A final challenge is that the lagged dependent variable may be capturing not actual persistence but misspecification if the effects of that misspecification are persistent (see e.g. Lawrence, 1998). We address this by instrumenting lagged holdings. We use the currency-cum-trade blocs established following the disintegration of the gold standard in the 1930s and the sovereign defaults of the same period to form instruments for 1943 holdings. ${ }^{23}$ The collapse of the gold standard after the UK and the US abandoned their fixed parities with respect to gold in 1931 and 1933 led to the formation of a sterling bloc including most (but not all) Commonwealth countries that maintained a currency peg, either formal or informal, to the British currency. ${ }^{24}$ It led also to the creation of a dollar bloc which included along

\footnotetext{
${ }^{20}$ We argue, in other words, that they satisfy both the relevance and exclusion restrictions for a valid instrument.

${ }^{21}$ This is different from the case envisaged by e.g. Okawa and van Wincoop, who consider a crosssection with more than one source country and a commensurately large number of destination countries. The source and destination dummies should also be time-varying in a panel with a time dimension, i.e. one would need for each period separate source and destination country dummies (see Okawa and van Wincoop, 2012, footnote 10 p. 212).

${ }^{22}$ Which would otherwise exhaust our degrees of freedom; a further reason for including regional effects is that multilateral resistance terms should be broadly similar within a region, especially if the latter is relatively homogeneous in terms of countries and distance vis-à-vis the US.

${ }^{23}$ An alternative previously used in the literature to estimate the impact of a lagged dependent variable and inertia effects (e.g. Eichengreen and Irwin, 1998) is to use the Griliches (1961)-Liviathan (1963) or the Hatanaka (1974) corrections, which account for the fact that the lagged dependent variable might be simply picking up persistent error terms. It is difficult to implement these corrections in our context, however. We do not have lags of the lagged dependent variable (i.e. we have data only for 1943, not for 1942 or any preceding year) which would yet be needed in this case. Another problem is that these corrections typically use the predicted value of the lagged dependent variable from the lags of the remaining model variables. In so doing, we could therefore introduce in the regression with 2010 holdings a potentially endogenous regressor (the gravity-determined component of 1943 holdings), which is also potentially collinear with the gravity variables used to also explain 2010 holdings.

${ }^{24}$ Most of these countries then moved together to impose protectionist and discriminatory trade measures in the context of the Ottawa Agreements.
} 
with the US dollar the currencies of Canada and various Latin American countries. It led to the creation of a "Reichsmark bloc" comprised of Germany together with much of Central and Eastern Europe, all of which introduced capital controls. Finally it led to the creation of a "gold bloc" of continental European countries, which maintained the gold standard through the first half of the 1930s.

These policy measures taken in the 1930s plausibly heightened global market segmentation and affected the incentive and ability of US investors to invest in certain countries. They can therefore be expected to be reasonably well correlated with 1943 holdings. There are no reasons to expect that they should directly affect 2010 holdings, since the measures in question were reversed after World War II. We therefore use as instruments a set of dummies that equal one when a country participated in the sterling, dollar, Reichsmark or gold bloc or introduced capitalcontrol and protectionist measures. ${ }^{25}$

Another instrument for 1943 holdings is whether a country defaulted on its sovereign debt in the 1930s. Sovereign defaults could have affected US bond holdings in 1943 in two ways: through their depressing impact on the market values of the holdings (due to debt write-downs); and through their adverse impact on the perceived creditworthiness of borrowing countries (which might in turn have lessened the incentives of US investors to invest in these countries). By contrast, the sovereign defaults of the 1930s are unlikely to still matter for 2010 bond holdings. Empirical studies for emerging markets post-1945 suggest that the loss of reputation and access to international capital markets that follows a sovereign default is relatively shortlived (see e.g. Borensztein and Panizza, 2009), certainly relative to the 70 year time span considered here. We therefore use as instruments a set of dummies that equals one when a country was at least one year in external or domestic default between 1929 and 1941, drawing on data in Reinhart and Rogoff (2011).

\section{Stylised facts}

Annex A2 reports data on US investors' holdings of foreign bonds scaled by GDP in 1943 and 2010. Such holdings accounted for about 1\% of US GDP in 1943 but over $10 \%$ of US GDP in 2010, reflecting the progress of financial globalization. Scaling US investors' holdings of foreign bonds by total foreign security holdings (the sum of bonds, equities and money market instruments) shows that such bonds accounted for about $60 \%$ of US investors' holdings of foreign securities during World War II. In 2010 , in contrast, that share had declined to $25 \%$, with equity holdings accounting for almost $70 \%{ }^{26}$

Considering US foreign assets in general (and not only foreign security holdings), there is evidence that the US position as "banker to the world" (of holding risky foreign assets and issuing safe foreign liabilities, as emphasized by e.g. Gourinchas and Rey, 2007) was already evident in the 1940s. Gourinchas, Rey and Truempler (2011) estimate that the share of "risky" and illiquid securities (defined as direct investment and equity claims in total US external assets) was over 50\% in 1971

\footnotetext{
${ }^{25}$ As documented in Eichengreen and Irwin (1995, 2010) and Wolf and Ritschl (2011).

${ }^{26}$ A major difference between 1943 and 2010, it would appear, is that US investors today hold riskier securities (insofar as equities are riskier than bonds, which is the conventional presumption).
} 
and $60 \%$ in $2007 .{ }^{27}$ Our estimates for 1939 and 1945 (using data reported in the 1943 US Treasury survey) are also in the order of $60 \%$. Evidently the pattern of liquidity and maturity transformation on the US external balance sheet has not changed much over the last 70 years. $^{28}$

In Annex A2 US investors' holdings of foreign dollar-denominated bonds are scaled by total US foreign bond holdings. This ratio can be thought of as measuring the extent of the home-currency (dollar) preferred habitat effect in the two eras. This too has remained broadly stable. In both 1943 and 2010, the ratio stands at about 66$70 \%$, suggesting that the preference for dollar-denominated securities on the part of US investors has changed relatively little over the period.

Figures 1 and 2 put past and present US investors' holdings of foreign bonds on the map. Countries are ranked by the absolute amount of US holdings. Each colour corresponds to a quartile of the distribution of US holdings to which countries in the sample belong. For instance, the dark grey shade corresponds to the top quartile, while the light grey shade corresponds to the bottom quartile. The pull of gravity is apparent in both maps. That is to say, there are a substantial number of dark-grey countries close to the US in North and South America in 1943 and 2010 alike. But there are also such countries in more distant locations. A striking difference between then and now is Cuba, for which US holdings of bonds were substantial in 1943 (as large as holdings of Italian and Japanese bonds, for example) but negligible in 2010. This reflects the significant change in the former US colony's political situation after the revolution of $1959 .^{29}$ It will be important to control for this in subsequent empirical work.

Figures 3a and 3b plot the logarithm of US foreign bond holdings in 1943 and in 2010 against log distance to the investment destination. The relationship is negative in 1943, in line with theory, but not in 2010. For 2010 this may reflect the presence in our sample of a number of offshore financial centres that are conduits for international financial investment, flows to which may in fact mainly be capturing US investments in other final destinations. We will therefore want to test for the sensitivity of our empirical results to the exclusion of these centres (as defined in IMF, 2006). ${ }^{30}$ Figures 3c and 3d suggest some tendency for US foreign bond holdings to increase with destination-country size, although there are exceptions.

\footnotetext{
${ }^{27}$ They similarly note that the share of "safe" and liquid securities (defined as bank loans and debt instruments in total US external liabilities) was 67 percent in 1971 and 63 percent in 2007.

${ }^{28}$ Data in the 1943 survey were not reported in a way such that we could calculate the corresponding shares of "safe" and liquid securities in US foreign liabilities for 1939 and 1945, however. It is yet to be noted that the US net foreign investment position declined throughout the 1930s (despite its persistent trade surpluses), reflecting large safe haven flows of short-term foreign capital from Europe to the US (see e.g. Lewis, 1945). This is also consistent with the view that the US was already acting as a "banker to the world".

${ }^{29}$ Another similar such case is Bolivia.

${ }^{30}$ In line with Lane and Milesi-Ferretti (2008b) and Forbes (2010). 18 countries of our sample were considered in 2006 by the IMF to be offshore financial centres, namely: the Bahamas, British Honduras (Belize), British Malaya (Singapore), British Mediterranean Possessions (Cyprus, Malta), British Oceania, British West Indies, Costa Rica, Eire (Ireland), Hong Kong, Liechtenstein, Luxembourg, Monaco, Netherlands West Indies, Panama, Philippines, Portuguese Asia (Macao), Switzerland, Uruguay.
} 
Figures 3e and 3f plot the logarithm of US holdings in 1943 and in 2010 against the log of bilateral trade with the US. The relationship is strongly positive, in line with the presumption that trade in goods and trade in financial assets are complements. Both variables are potentially endogenous, however, as noted above, and we will want to correct for this in the empirical estimation.

Figures 4a plots the logarithm of US foreign bond holdings in 1943 against log 2010 holdings. The positive correlation is striking. Not that this is not limited to bonds but seems to extend also to other financial instruments. Figures $4 \mathrm{~b}$ and $4 \mathrm{c}$ show similar scatter plots using total foreign security holdings (i.e. bonds, equities and money market instruments) and dollar-denominated bonds. The positive correlations between current and lagged holdings are equally striking there, further pointing to the possible existence of a history effect.

\section{Estimates for 2010}

Table 1 reports OLS estimates of Eq. (1) for US foreign bond holdings in 2010 for both the full sample and excluding offshore financial centres. We start in columns 1 and 2 by including only the core gravity-theoretic determinants: distance, relative output size and bilateral trade (instrumented as explained above). Distance enters with a counterintuitive positive sign, although its significance does not survive when we exclude offshore financial centres and control for omitted variables - see below. The effect of GDP share is nil. The intensity of bilateral trade is an important determinant of the worldwide allocation of US holdings. Its effect is large: a 1\% increase in US bilateral trade with a country translates into a roughly $1.6 \%$ increase in US holdings of its bonds.

In columns 3 and 4 we add our proxies for connectivity and familiarity. Distance loses its significance when the sample excludes offshore financial centres, as noted, while GDP size remains insignificant. Bilateral trade remains a significant and economically important determinant of foreign bond holdings in 2010.

The results suggest, in addition, that US investors invest significantly less in former US colonies. While this might seem surprising, it is important to note that the sample of former colonies - Cuba and the Philippines - is very special. The two other connectivity proxies (common language and legal origin) have no statistically significant effect on US foreign bond holdings.

How robust are the results to omitted variable bias and potential outliers? To address this we use OLS estimation with regional effects (columns 5 and 6) and robust-to-outlier estimation (columns 7 and 8). The impact of bilateral trade remains unchanged. Both GDP size and distance have no significant effect. Nor do the connectivity dummies. The exception is again the colonial dummy, but only for the sample excluding offshore centres and when estimating the regression with OLS and regional effects. ${ }^{31}$

\footnotetext{
${ }^{31}$ The colonial dummy dropped out due to multicollinearity in the robust-to-outlier estimation.
} 
Overall, our gravity estimates for US foreign bond holdings are consistent with those in other recent papers (e.g. Aviat and Coeurdacier, 2007; Lane and MilesiFerretti, 2008b; Martin and Coeurdacier, 2009), which challenge the conclusion of Portes and Rey (2005) that distance plays a dominant role in explaining the geographical allocation of a country's financial investments. Our evidence confirms that bilateral trade is a more robust and important driver, reflecting complementarities between trade in goods and trade in financial assets.

\section{Estimates for 1943}

The key gravity theoretic variables similarly explain much of the geographical variation in US foreign holdings 70 years ago. In the standard OLS estimations (columns 1 to 4 of Table 2), holdings decline with distance; they rise with country size and bilateral trade. ${ }^{32}$ A $1 \%$ increase in distance, size and trade are associated with a decline in US foreign bond holdings of about $0.7 \%$ and a rise in these holdings of $0.3 \%$ and $0.4 \%$, respectively. ${ }^{33}$

None of the connectivity proxies is found to have a significant effect, again with the exception of the Cuba-Philippines dummy. The latter has a positive effect on US foreign bond holdings in 1943, i.e. opposite in sign to the estimates for 2010. Again, this reflects the influence of Cuba and the significant economic interests the US had in its former colony prior to the 1959. Our estimates suggest that the US held six times more bonds in Cuba and the Philippines than in other countries with otherwise comparable characteristics.

Adding regional effects and controlling for outliers does not change the findings. The qualitative effects of size, bilateral trade and colonial links remain and in some cases become larger in economic magnitude. As in the case of 2010 holdings, the effect of distance is no longer statistically significant, again suggesting that distance is a less robust determinant of the geographical allocation of a country's financial investments than bilateral trade.

\footnotetext{
${ }^{32}$ Contemporaries already believed in the complementarity of trade in goods and finance: "the idea of foreign lending was advocated as a make-work measure because it stimulated exports” (US Treasury, 1947, p. 39).

${ }^{33}$ Interestingly, the impact of bilateral trade is more consistently significant when the sample excludes the same set of countries enumerated above as offshore centres. Of course, countries classified as offshore financial centres by the IMF today were not necessarily offshore financial centres in a meaningful sense in 1943. Attempts to systematically identify offshore financial centres date back only to 1990, with the creation of the Financial Action Task Force, an international body hosted by the OECD which aims to set standards and promote effective implementation of legal, regulatory and operational measures for combating money laundering, terrorist financing and other related threats to the integrity of the international financial system. Other international organisations have aimed to list offshore financial centres since then, including the IMF and the Financial Stability Forum (today's Financial Stability Board). To the extent that offshore financial centre status makes a difference for our results in 1943 (note that such differences are only modest), this suggests that these countries also vary from the rest of the sample along other dimensions.
} 
We conducted a range of additional checks to establish robustness. ${ }^{34}$ First, we estimated the gravity equations for 2010 and 1943 holdings simultaneously using seemingly unrelated regressions (SUR), since error terms for specific countries are likely to be correlated across the two periods, and found the same results.

We dropped bilateral trade to test whether it could be disguising the explanatory impact of distance. The latter remained insignificant. We used trade data for 1928 (a year presumably not distorted by the Great Depression, the trade protectionism of the 1930s and the outbreak of World War II). This did not change our core result that the impact of bilateral trade is positive, significant and large.

Next we added a dummy variable for whether countries were on the US side in World War II. Wartime lending was important for US investment positions in 1944, according to some contemporary accounts (e.g. Lewis, 1945). Our estimates, however, indicate no significant effect on 1943 bond holdings.

We entered separate dummy variables for the Philippines and Cuba (rather than a single variable for both one-time US colonies) and found that the large negative effect of colonial relationships for 2010 holdings is due to Cuba, while the large positive effect for 1943 holdings is due to both Cuba and the Philippines.

Finally we controlled for financial development, as proxied by the ratio of broad money to GDP (see e.g. King and Levine, 1993, for discussion of this measure). Whatever the sample used, financial development was found to play no independent role in explaining the geographical allocation of US bond holdings abroad in $1943 .{ }^{35}$

\section{Testing for the history effect}

To what extent do US investors' holdings of foreign bonds 70 years ago help predict current holdings? Table 3 reports gravity estimates for US foreign bond holdings in 2010 when the logarithm of 1943 holdings is added as a regressor, obtained using OLS (columns 1 to 4), including regional effects (columns 5 and 6), and using robustto-outliers estimation (columns 7 and 8).

Not only do 1943 holdings help to predict 2010 holdings, but their effect is large. In the OLS estimates, a 1\% increase in US holdings in a country 70 years ago is associated with higher holdings of about $1 \%$ in this country today. The adjusted- $R^{2}$ jumps from roughly 35\% to 50\% when we add 1943 holdings. In other words, the pattern of 1943 holdings explains about 15 percentage points of the allocation by US investors of their current bond holdings around the world. The result is unchanged when we exclude offshore centres and include common language, colony and legal system dummies (columns 1 to 4 ). It remains essentially unchanged in significance

\footnotetext{
${ }^{34}$ These additional results were obtained using OLS estimation with regional effects and including all connectivity proxies. They are not reported here to save space, but are available upon request from the authors.

${ }^{35}$ Data on broad money were taken from League of Nations (1938/1939) and were available for 29 countries only, which might also explain the poor performance of financial development as an explanatory variable here.
} 
and economic magnitude if one controls for omitted variables (as in columns 5 and 6) and outliers (as in columns 7 and 8).

Some readers will worry that a lagged dependent variable with a large estimated coefficient is indicative of misspecification. As discussed in Section 3, we address this by instrumenting lagged holdings with a set of currency bloc and sovereign default dummies for the 1930s. As shown in Table 4, instrumented 1943 holdings are a significant determinant of the geographical allocation of US investors' holdings in 2010, with an estimated elasticity ranging from 0.7 to 1.6, depending on specification (columns 1 to 6 ). The increase in the adjusted $R^{2}$ is slightly less than before, i.e. from about $35 \%$ to $45 \%$, suggesting that roughly $10 \%$ of today's worldwide allocation by US investors of foreign bond holdings can be ascribed to earlier investments. We again obtain similar results if we exclude offshore centres or control for connectivity or regional effects and outliers.

The $F$-statistic of the first-stage regression is always statistically significant (except in the specification of column 5), which suggests that our instruments have significant explanatory power for lagged holdings. Power is not strong, however, given that the statistic exceeds the threshold value of 10 recommended by Stock, Wright and Yogo (2002) only for the specification of column $2 .{ }^{36}$ Sargan's statistic on the other hand never rejects the null that our instruments are uncorrelated with the error term, providing evidence that they do not affect 2010 holdings directly and, as such, are valid.

Readers may also ask whether this evidence of a history effect is peculiar to bonds. Table 5 therefore reports estimates using equity rather than bond holdings as the dependent variable. The history effect is again evident, even after controlling for connectivity, regional effects, and outliers. Its estimated impact is similar to that for bonds, with a $1 \%$ increase in US equity holdings in a country 70 years ago being associated with higher holdings of about $1.2 \%$ in the same country today. The increase in the adjusted $R^{2}$ again suggests that approximately $13 \%$ of today's worldwide allocation by US investors of their total foreign equity holdings can be explained by holdings 70 years ago - very similar to the magnitudes for bonds. ${ }^{37} \mathrm{We}$ again obtain similar results when testing for a history effect in US investors' total security holdings (i.e. bonds and equities), in Table 6 .

We again subjected our results to further sensitivity tests. As an alternative lagged regressor, we included 1943 holdings freed from gravity effects -or, in other words, the residual of the gravity regressions for 1943 holdings of Table 2. Quite expectedly, this had no impact on the results, since the influence of gravity theoretic variables is already controlled for in the estimation. We also controlled for the quality

\footnotetext{
${ }^{36}$ Note, however, that the estimates are based on a much smaller sample than the baseline, since we lose roughly half of the observations.

${ }^{37}$ The data on US foreign equity holdings also allow us to test the presence of a history effect in a theoretical framework different from the gravity model, namely the international capital asset pricing model (CAPM). The simplest international-CAPM model with homogenous investors would suggest that a representative investor should hold the world market portfolio (Coeurdacier and Rey, 2011); in other words, the share of US investments in the equities of a particular country should be proportional to the share of this country's equity market in global markets. We regressed US foreign equity holdings in 2010 on countries' equity market capitalisation (taken from S\&P-IFC) and lagged holdings and found significant evidence for the history effect, albeit not when controlling for regional effects.
} 
of institutions, by adding an index of government quality compiled by the International Country Risk Guide in the regressions; the history effect remained unaltered. We controlled for the presence of US military bases, a proxy for ease of enforcing US investors' property rights; again this did not change the results. We controlled for the impact of dollarisation, as proxied by the share of dollardenominated bonds in US foreign bond holdings (in either 1943 or 2010), with no effect on our findings. We controlled for countries with histories of high macroeconomic instability -as proxied by the depreciation of their nominal exchange rate against the US dollar between 1950 and 2010- which again did not affect the history effect. ${ }^{38}$

\section{Dollar- and foreign-currency denominated bonds}

One might expect sunk costs and therefore the history effect to be even larger for bonds issued in currencies other than the dollar. US investors will have to learn not just about the creditworthiness of the foreign issuer but also about the characteristics of its currency; additional frictions may also come into play, such as the absence of liquid markets to hedge currency risk.

Table 7 provides estimates of the history effect separately for dollar and nondollar bond holdings (columns 2 to 5 and columns 7 to 10, respectively). These equations are estimated on a sample of 41 countries for which data on the currency of denomination of bond holdings is available in both 1943 and 2010. Columns 1 and 6 report pro memoria plain-vanilla gravity model estimates as benchmarks against which to gauge the new results.

The history effect is prominent for both dollar and non-dollar bonds. But it is more important for non-dollar bonds, as the preceding arguments suggest. The estimated elasticity of today's holdings relative to lagged holdings is $0.8-1.1$ for dollar bonds but close to 1.6 for non-dollar bonds. Moreover, the adjusted $R^{2}$ increases by roughly 30 percentage points for non-dollar bonds, as opposed to 15 percentage points for dollar bonds. On balance, then, the history effect is about twice as large for nondollar bonds, indicative of larger sunk costs giving rise to stronger persistence. ${ }^{39}$

\footnotetext{
${ }^{38}$ We also tested for the "history effect" in gravity equations for trade, with lagged trade being defined as aforementioned as average bilateral trade with the US in 1931-1940 (or, alternatively, in 1928) and current trade defined as average bilateral trade with the US in 2000-2010. We found evidence of a history effect in trade not unlike that in finance. This is in line with the findings of Eichengreen and Irwin (1998), who utilized data for 1928 and 1938.

${ }^{39}$ We also estimated the impact of currency denomination in a single model, by interacting lagged holdings with a dummy equalling one for countries with a "high" (i.e. above median) share of dollar bond holdings; we found similar evidence that the history effect was 30-50\% lower in economic magnitude for these countries, although the effect was not statistically significant. Moreover, we estimated a specification where the dependent variable is the share of foreign dollar bonds in total foreign bond holdings (these equations are estimated by tobit, since the share is bounded between 0 and 1). They again confirm the existence of a "history effect," albeit smaller in economic magnitude and somewhat weaker in statistical significance, with the effect becoming insignificant only in the specification where we controlled for connectivity and regional effects simultaneously.
} 


\section{Conclusions and implications}

We have shown that history plays a role in the geography of international finance. Using data on US investors' holdings of foreign bonds in 88 countries in 1943, we have documented a "history effect" in which US bilateral holdings 70 years ago help to explain the allocation of US holdings around the world today.

This effect is statistically significant, robust and economically important even after controlling for the arguments of the standard gravity model. We interpret it in terms of the beachhead and path dependence effects arising from sunk costs of market entry and exit. Our estimates suggest that a 1\% increase in US holdings in a country 70 years ago is associated with holdings of some $1 \%$ higher in the same country today. They suggest that 10 to $15 \%$ of the cross-sectional variance of today's holdings is attributable to the effect of the holdings of 70 years ago.

Our findings are robust to including standard measures of informational frictions such as common language, legal origin, and past colonial status. They are robust to controlling for omitted variable bias with regional fixed effects. They are robust to outliers. They extend to other securities besides bonds. The causal interpretation of the effect is buttressed by the observation that it remains when one instruments lagged holdings with dummies that aim to capture the effects of the disintegration of the gold standard and of the sovereign defaults of the 1930s, which contributed to the growing segmentation of global financial markets during the Great Depression.

The early literature on gravity in international finance found that the geographical component of cross-border financial flows and holdings is substantial that international financial markets are not frictionless but segmented by market size, informational asymmetries and familiarity effects. Subsequent studies established the importance of complementarities between trade in goods and trade in assets. In this paper we have shown that history also matters - that historical patterns persistently weigh on the geography of bilateral asset holdings.

We also find that the history effect is twice as large for non-dollar bonds, which we interpret as reflecting larger sunk costs for US financial investments in currencies other than the dollar. These findings underscore the need for more analysis of the currency composition of countries' foreign assets and liabilities, along with their causes and effects. They also underscore how the role of the dollar as a global investment currency today is partly a legacy of this earlier era when it dethroned sterling as the leading international currency. 


\section{References}

Ahearne, A., W. Griever, and F. Warnock (2004), "Information Costs and Home Bias: an Analysis of US Holdings of Foreign Equities", Journal of International Economics, 62, pp. 313-336.

Anderson, J. and E. van Wincoop (2003), "Gravity with Gravitas: a Solution to the Border Puzzle”, American Economic Review, 93(1), pp. 170-192.

Antras, P. and R. Caballero (2007), "Trade and Capital Flows: A Financial Frictions Perspective,” NBER Working Paper, No. 13241.

Aviat, A. and N. Coeurdacier (2007), "The Geography of Trade in Goods and Asset Holdings”, Journal of International Economics, 71, pp. 22-51.

Baldwin, R. (1988), "Hysteresis in Import Prices: The Beachhead Effect”, American Economic Review, 74, pp. 773-785.

Baldwin, R. and P. Krugman (1989), "Persistent Trade Effects of Exchange Rate Shocks”, Quarterly Journal of Economics, 104, pp. 635-654.

Borensztein, E. and U. Panizza (2009), "The Costs of Sovereign Default”, IMF Staff Papers, 56, pp. 683-741.

Clemens, M. and J. Williamson (2004), "Wealth Bias in the First Global Credit Market Boom, 1870-1913”, Economic Journal, 114, pp.311-455.

Coeurdacier, N. and P. Martin (2009), “The Geography of Asset Trade and the Euro: Insiders and Outsiders”, Journal of the Japanese and International Economies, 23, pp. 90-113.

Coeurdacier, N. and H. Rey (2011), "Home Bias in Open Economy Financial Macroeconomics”, Journal of Economic Literature, forthcoming.

Daude, C. and M. Fratzscher (2008), "The Pecking Order of Cross-Border Investment”, Journal of International Economics, 74, pp. 94-119.

De Santis, R. and G. Gerard (2009), "International Portfolio Reallocation: Diversification Benefits and European Monetary Union”, European Economic Review, 53(8), pp. 1010-1027.

Dixit, A. (1989), "Hysteresis, Import Penetration and Exchange Rate Pass-through", Quarterly Journal of Economics, 104, pp. 205-228.

Eichengreen, B. (1989), “The U.S. Capital Market and Foreign Lending, 1920-1955,” in J. Sachs (Ed.), Developing Country Debt and Economic Performance, Volume 1, The International Financial System, Chicago: University of Chicago Press, pp.107158.

Eichengreen, B. and D. Irwin (1995), “Trade Blocs, Currency Blocs and the Reorientation of World Trade in the 1930s", Journal of International Economics, vol. 38(1-2), pp. 1-24.

Eichengreen, B. and D. Irwin (1998), "The Role of History in Bilateral Trade Flows", in The Regionalization of the World Economy, J. Frankel (Ed.), University of Chicago Press, pp. 33-57. 
Eichengreen, B. and D. Irwin (2010), "The Slide to Protectionism in the Great Depression: Who Succumbed and Why?” Journal of Economic History, vol. 70(4), pp. 871-897.

Eichengreen, B. and P. Luengnaruemitchai (2006), "Bond Markets as Conduits for Capital Flows: How does Asia Compare?” in T. Ito and A. Rose (Eds.), International Financial Issues in the Pacific Rim: Global Imbalances, Financial Liberalization, and Exchange Rate Policy, pp. 267-313.

Eichengreen, B. and R. Portes (1986), "Debt and Default in the 1930s: Causes and Consequences,” European Economic Review, 30(3), pp. 599-640.

Esteves, R. (2011), "The Belle Epoque of International Finance: French Capital Exports, 1880-1914,” Working Paper no. 534, Department of Economics, University of Oxford.

Forbes, K. (2010), “Why do Foreigners Invest in the US?” Journal of International Economics, 80, pp. 3-21.

Griever, W. and F. Warnock (2001), "The US System for Measuring Cross-Border Investment in Securities: a Primer with a Discussion of Recent Developments", Federal Reserve Bulletin, 87(10), pp. 633-650.

Gourinchas, P.-O. and H. Rey (2007), "From World Banker to World Venture Capitalist: US External adjustment and the Exorbitant Privilege" in R. Clarida (Ed.), G-7 Current Account Imbalances: Sustainability and Adjustment, Chicago: University of Chicago Press, pp. 11-55.

Gourinchas, P.-O., H. Rey and K. Truempler (2011), “The Financial Crisis and the Geography of Wealth Transfers”, mimeo.

Griliches, Z. (1961), “A Note on the Serial Correlation Bias in Estimates of Distributed Lags”, Econometrica, 29, pp. 65-73.

Hatanaka, M. (1974), “An Efficient Two-Step Estimator for the Dynamic Adjustment Model with Autoregressive Errors”, Journal of Econometrics, 2, pp. 199-220.

International Monetary Fund, (2006), Offshore Financial Centres, the Assessment Program: a Progress Report, Washington D.C.

King, R. and R. Levine (1993), “Finance and Growth: Schumpeter Might be Right”, Quarterly Journal of Economics, 108(3), pp. 717-37.

Lane, P. and J. Shambaugh (2010), "Financial Exchange Rates and International Currency Exposures”, American Economic Review, 100(1), pp. 518-540.

Lane, P. and G.-M. Milesi-Ferretti (2008a), “The Drivers of Financial Globalization”, American Economic Review: Papers and Proceedings, 98(2), pp. 327-332.

Lane, P. and G.-M. Milesi-Ferretti (2008b), "International Investment Patterns", Review of Economics and Statistics, 90(3), pp. 538-549.

La Porta, R., F. Lopez de Silanes and A. Schleifer (2006), "What Works in Securities Law”, Journal of Finance, vol. LXI (1), pp. 1-32.

Lary, H. B. (1943), The United States in the World Economy, Economic Series, No. 23, US Department of Commerce, Washington, DC.

Lawrence, R. (1998), “Comment on Eichengreen and Irwin”, in The Regionalization of the World Economy, J. Frankel (Ed.), University of Chicago Press, pp. 57-59. 
League of Nations (Société des Nations), Statistiques Monétaires, Tableaux sommaires internationaux (Composition et mouvement de la circulation monétaire), Monnaie et Banque, 1938/1939, League of Nations: Geneva.

Lewis, C. (1938), America's Stake in International Investments, Brookings Institution, Washington DC.

Lewis, C. (1945), Debtor and Creditor Countries: 1938, 1944, Brookings Institution, Washington DC.

Lewis, C. (1948), The United States and Foreign Investment Problems, Brookings Institution, Washington DC.

Liviatan, N. (1963), “Consistent Estimation of Distributed Lags”, International Economic Review, 4, pp. 44-52.

Maddison, A. (2010), Statistics on World Population, GDP and Per Capita GDP, 1$2008 A D$, University of Groningen, Groningen.

Obstfeld, M. and K. Rogoff (2000), “The Six Major Puzzles in International Macroeconomics: is there a Common Cause?” NBER Macroeconomics Annual.

Okawa, Y. and E. van Wincoop (2012), “Gravity in International Finance”, Journal of International Economics, 87, pp. 205-215.

Portes, R. and H. Rey (2005), “The Determinants of Cross-Border Equity Flows”, Journal of International Economics, 65, pp. 269-296.

Rose, A. and M. Spiegel (2004), “A Gravity Model of Sovereign Lending: Trade, Default and Credit”, IMF Staff Papers, 51, pp. 64-74.

Reinhart, C. and K. Rogoff (2011), “From Financial Crash to Debt Crisis”, American Economic Review, 101(5), pp. 1676-1706.

US Treasury (1947), Census of American-owned Assets in Foreign Countries, US Treasury Department, Office of the Secretary, Washington DC.

US Treasury, Federal Reserve Bank of New York, Board of Governors of the Federal Reserve System (2011), Report on U.S. Portfolio Holdings of Foreign Securities (as of December 31, 2010).

Stock, J., J. Wright and M. Yogo (2002), “A Survey of Weak Instruments and Weak Identification in Generalized Methods of Moments”, Journal of Business and Economic Statistics, 20, pp. 518-529.

Van Nieuwerburgh S. and L. Veldkamp (2009), "Information Immobility and the Home Bias Puzzle”, Journal of Finance, 64(3), pp. 1187-1215.

Wolf, N. and A. Ritschl (2011), "Endogeneity of Currency Areas and Trade Blocs: Evidence from a Natural Experiment”, Kyklos, vol. 64(2), pp. 291-312. 
Figure 1: US foreign bond holdings - 1943

(USD million)

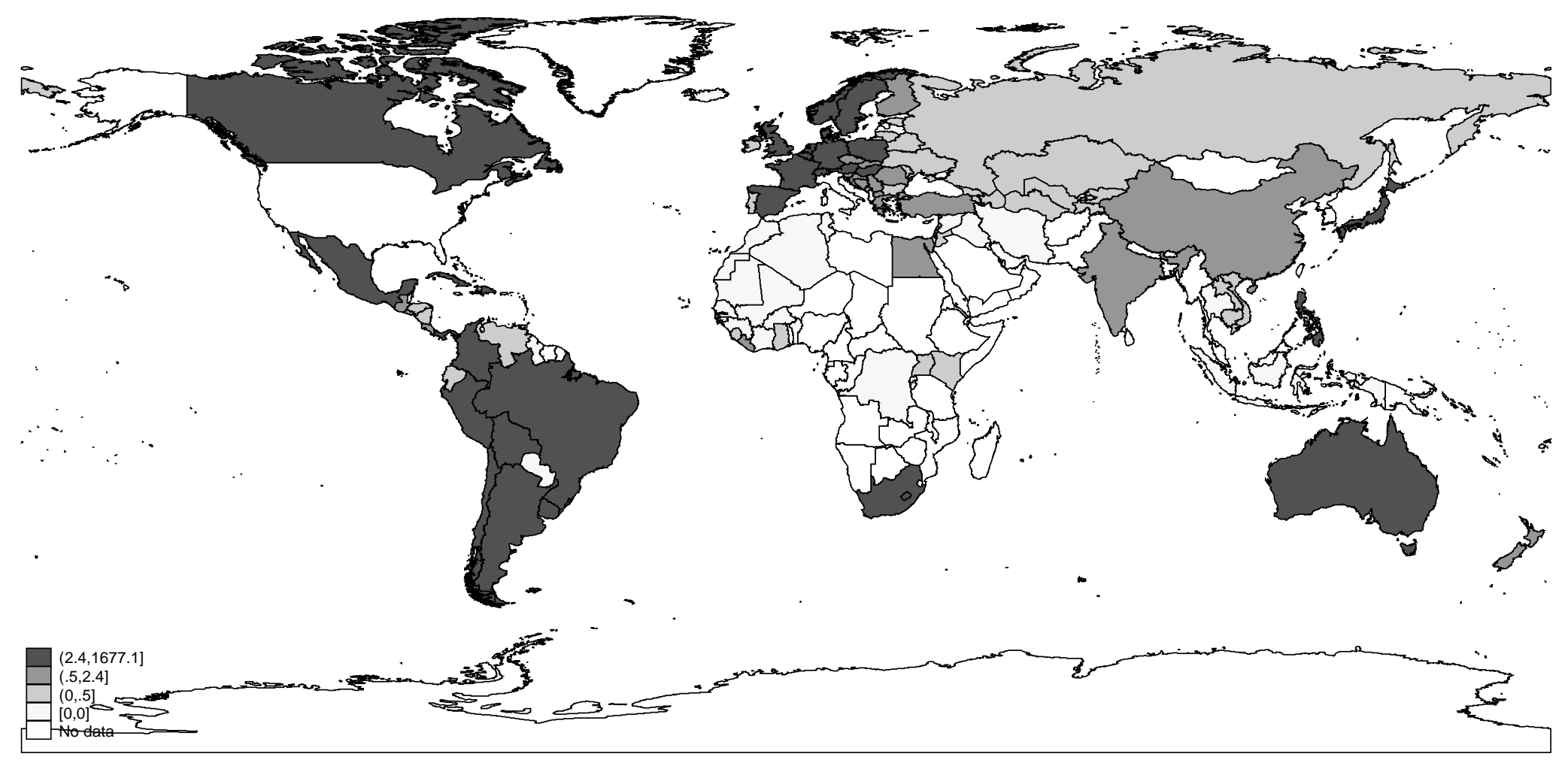

Note: The figure shows the geographical allocation in 1943 of US foreign bond holdings in the 88 countries reporting data in the 1943 survey (see US Treasury, 1947), which in total amounted to \$2,269 million (at market value). The map shows countries according to 2010's national borders. Each shade of colour corresponds to a specific quartile of the distribution of total US holdings (dark grey = top quartile; light grey = bottom quartile). 
Figure 2: US foreign bond holdings - 2010

(USD million)

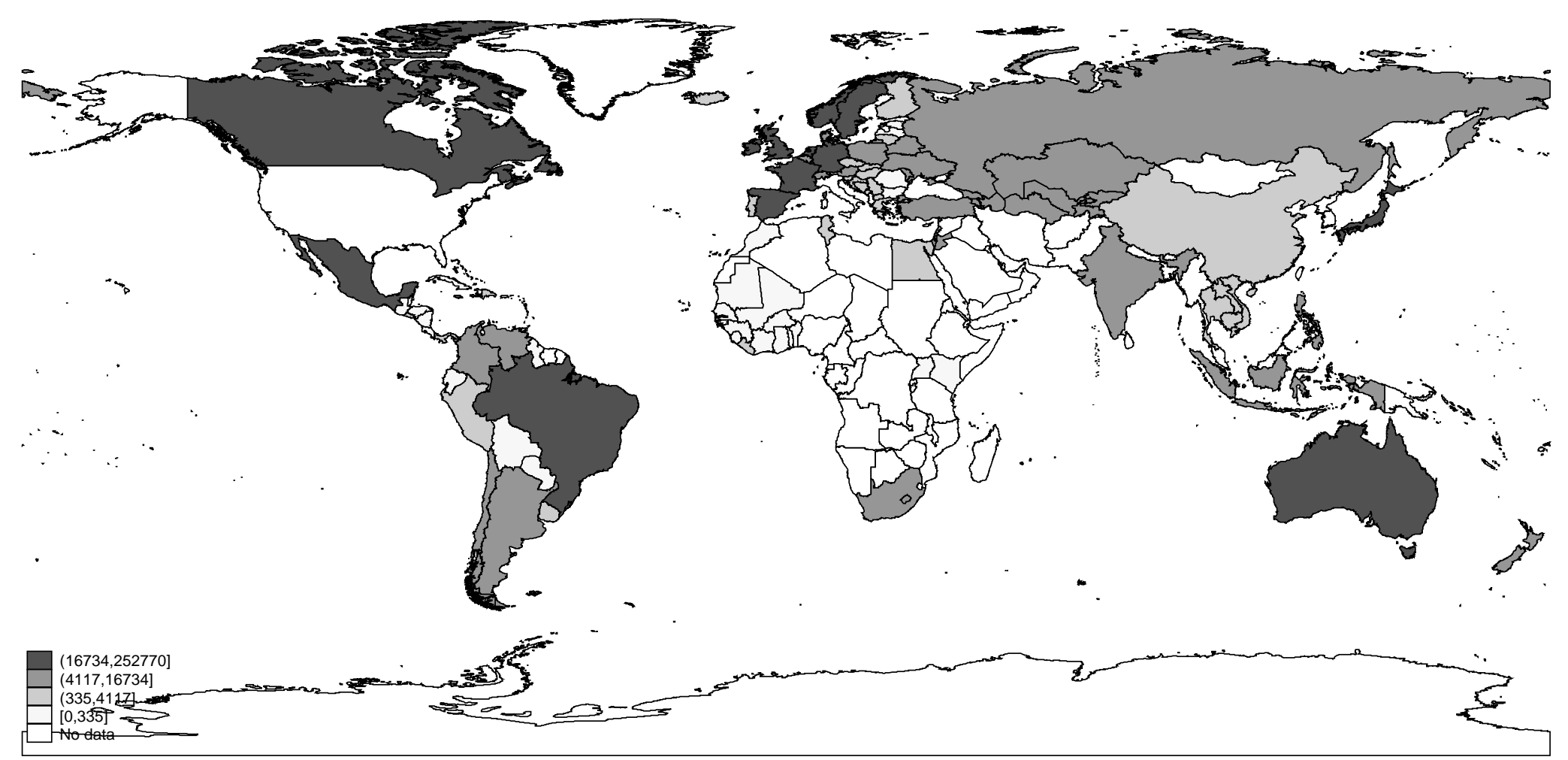

Note: The figure shows the geographical allocation in 2010 of US foreign bond holdings in the 88 countries of our sample (see US Treasury, 2011), where available, which in total amounted to \$1,604 billion at market value. The map shows countries according to 2010's national borders. Each shade of colour corresponds to a specific quartile of the distribution of total US holdings (dark grey = top quartile; light grey = bottom quartile). 
Figures 3a-3f: US foreign bond holdings vs. theoretic gravity determinants

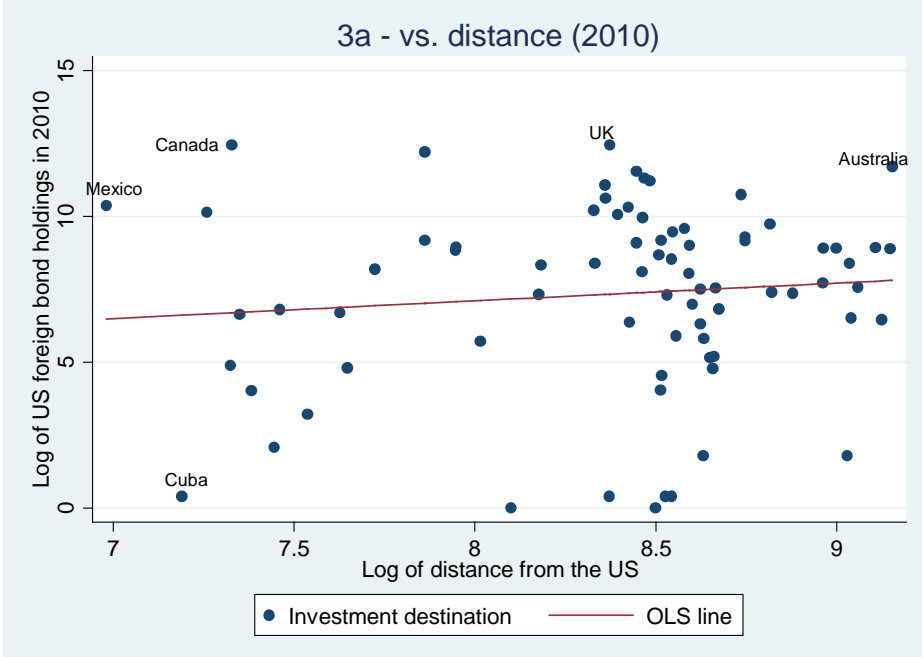

3b - vs. distance (1943)

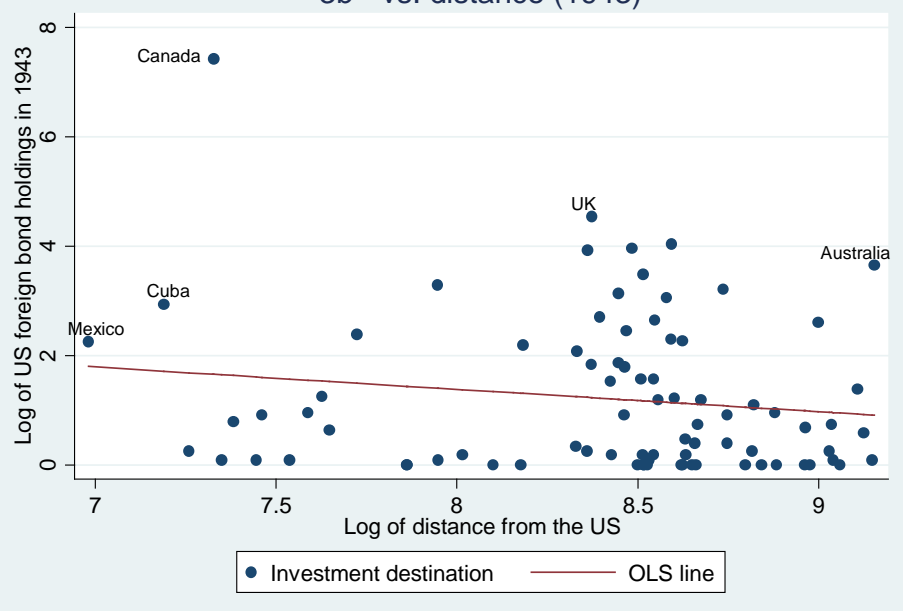

3c - vs. GDP (2010)

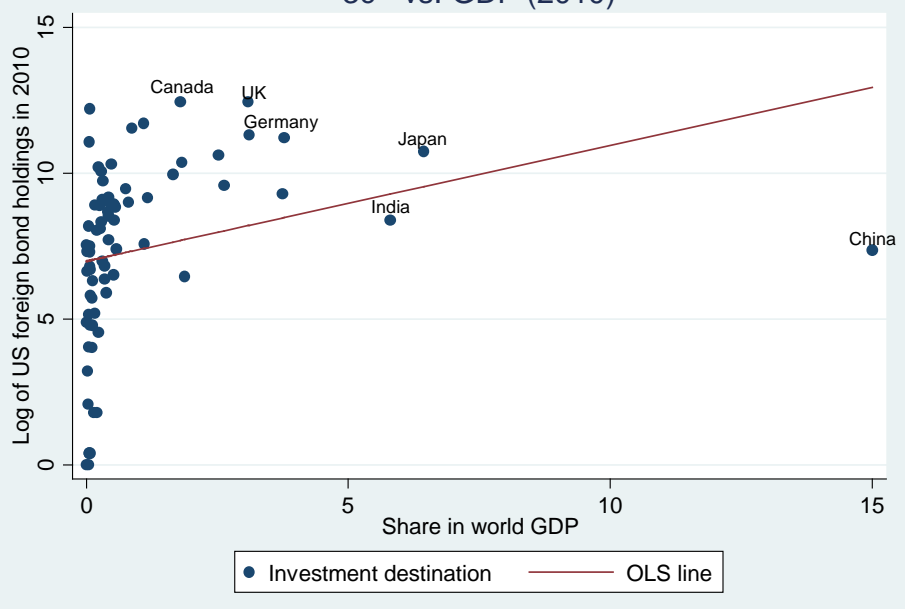



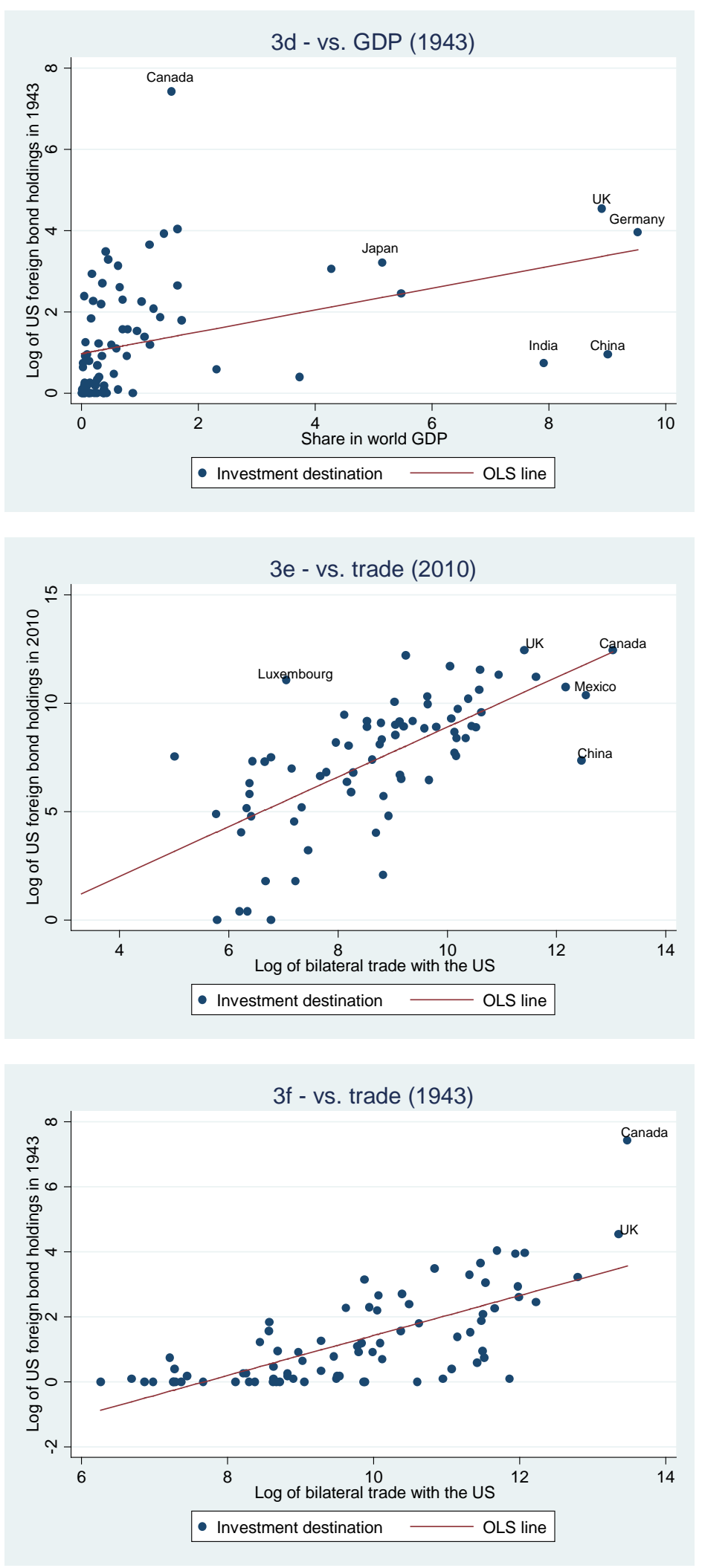

Note: The figures plot the logarithm of US foreign bond holdings in 1943 and 2010 against (a, b) the logarithm of the distance (in miles) from the US to the respective investment destination country; (c, d) its share in world GDP and (e, f) the logarithm of bilateral trade with the US (sum of bilateral exports and imports). 
Figures 4a-4c: US foreign security holdings: 1943 vs. 2010
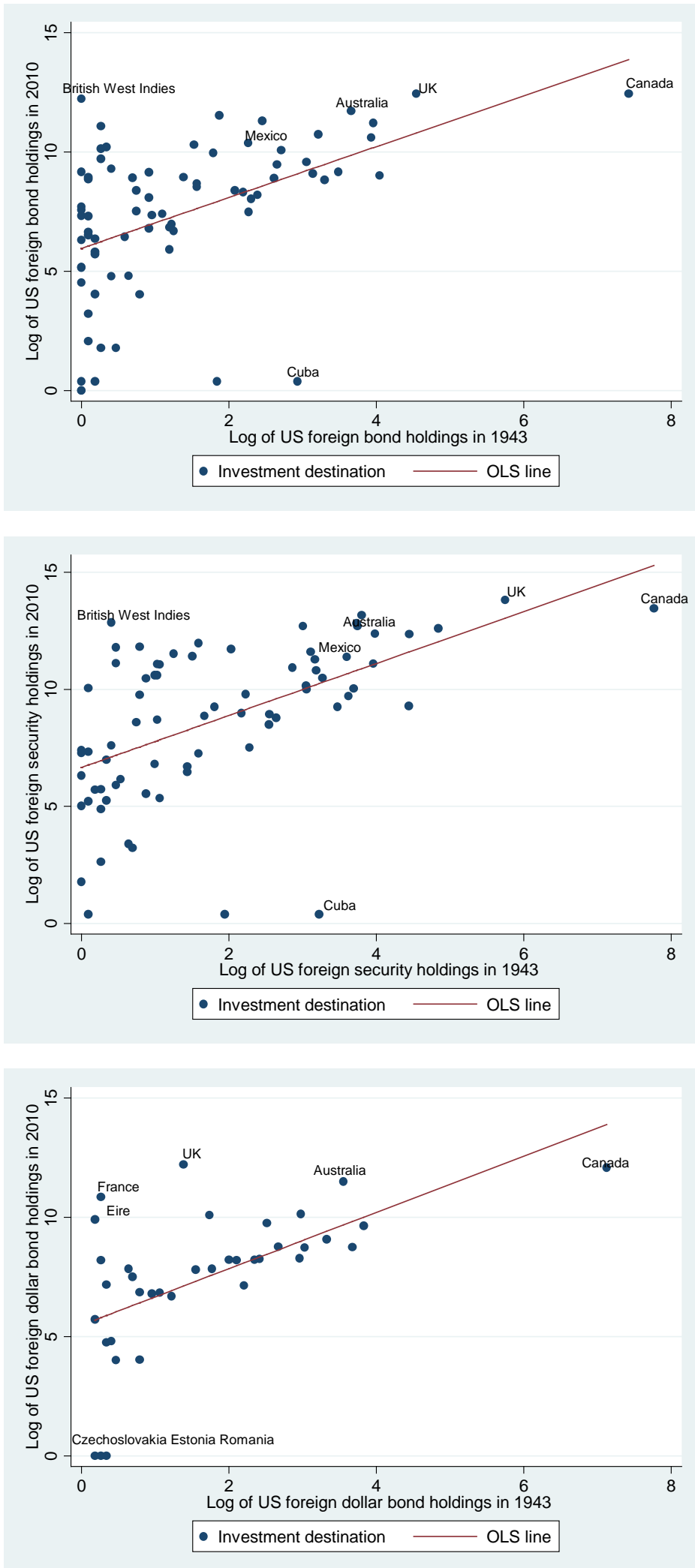

Note: The figures plot the logarithm of US foreign (a) bond, (b) security and (c) dollar-denominated bond holdings in 1943 against the logarithm of the corresponding holdings in 2010 in the respective investment destination country. 
Table 1: Gravity estimates - US foreign bond holdings in 2010

\begin{tabular}{|c|c|c|c|c|c|c|c|c|}
\hline & $\begin{array}{c}(1) \\
\text { Full } \\
\text { sample }\end{array}$ & $\begin{array}{c}(2) \\
\text { Excl. } \\
\text { offshore } \\
\text { centres } \\
\end{array}$ & $\begin{array}{c}\text { (3) } \\
\text { Full } \\
\text { sample }\end{array}$ & $\begin{array}{c}(4) \\
\text { Excl. } \\
\text { offshore } \\
\text { centres } \\
\end{array}$ & $\begin{array}{c}\text { (5) } \\
\text { Full } \\
\text { sample }\end{array}$ & $\begin{array}{c}(6) \\
\text { Excl. } \\
\text { offshore } \\
\text { centres } \\
\end{array}$ & $\begin{array}{c}\text { (7) } \\
\text { Full } \\
\text { sample }\end{array}$ & $\begin{array}{c}(8) \\
\text { Excl. } \\
\text { offshore } \\
\text { centres } \\
\end{array}$ \\
\hline Log (distance from US) & $\begin{array}{l}1.125^{* *} \\
(0.553)\end{array}$ & $\begin{array}{l}1.392^{* *} \\
(0.690)\end{array}$ & $\begin{array}{l}1.099 * * \\
(0.532)\end{array}$ & $\begin{array}{c}0.802 \\
(0.668)\end{array}$ & $\begin{array}{c}1.400 \\
(1.991)\end{array}$ & $\begin{array}{l}-1.760 \\
(2.389)\end{array}$ & $\begin{array}{c}1.383 \\
(1.577)\end{array}$ & $\begin{array}{l}-0.154 \\
(1.931)\end{array}$ \\
\hline GDP size & $\begin{array}{c}0.064 \\
(0.175)\end{array}$ & $\begin{array}{c}0.054 \\
(0.187)\end{array}$ & $\begin{array}{c}0.051 \\
(0.177)\end{array}$ & $\begin{array}{c}0.081 \\
(0.191)\end{array}$ & $\begin{array}{c}0.155 \\
(0.169)\end{array}$ & $\begin{array}{c}0.218 \\
(0.209)\end{array}$ & $\begin{array}{c}0.131 \\
(0.144)\end{array}$ & $\begin{array}{c}0.124 \\
(0.152)\end{array}$ \\
\hline Log (trade with US) & $\begin{array}{c}1.592^{* * *} \\
(0.263)\end{array}$ & $\begin{array}{c}1.650^{* * *} \\
(0.303)\end{array}$ & $\begin{array}{c}1.619^{* * *} \\
(0.285)\end{array}$ & $\begin{array}{c}1.516^{* * *} \\
(0.321)\end{array}$ & $\begin{array}{c}1.889 * * * \\
(0.363)\end{array}$ & $\begin{array}{c}1.547^{* * *} \\
(0.409)\end{array}$ & $\begin{array}{c}1.728^{* * *} \\
(0.335)\end{array}$ & $\begin{array}{c}1.478^{* * *} \\
(0.373)\end{array}$ \\
\hline Common language dummy & & & $\begin{array}{l}-0.034 \\
(1.113)\end{array}$ & $\begin{array}{l}-0.700 \\
(2.406)\end{array}$ & $\begin{array}{c}0.225 \\
(1.208)\end{array}$ & $\begin{array}{l}-1.631 \\
(2.532)\end{array}$ & $\begin{array}{c}1.270 \\
(0.884)\end{array}$ & $\begin{array}{c}1.721 \\
(1.401)\end{array}$ \\
\hline Cuba-Philippines dummy & & & $\begin{array}{l}-2.582 \\
(1.670)\end{array}$ & $\begin{array}{c}-4.963 * * * \\
(0.942)\end{array}$ & $\begin{array}{l}-0.730 \\
(1.803)\end{array}$ & $\begin{array}{c}-3.687 * * \\
(1.608)\end{array}$ & $\begin{array}{l}-0.989 \\
(1.814)\end{array}$ & \\
\hline Common legal origin dummy & & & $\begin{array}{l}-0.134 \\
(1.230)\end{array}$ & $\begin{array}{c}1.061 \\
(2.373)\end{array}$ & $\begin{array}{l}-0.023 \\
(1.244)\end{array}$ & $\begin{array}{c}2.307 \\
(2.329)\end{array}$ & $\begin{array}{c}-0.684 \\
(1.131)\end{array}$ & $\begin{array}{l}-0.316 \\
(1.548)\end{array}$ \\
\hline Regional effects & NO & NO & NO & NO & YES & YES & YES & YES \\
\hline Constant & $\begin{array}{c}-15.801^{* * *} \\
(5.571)\end{array}$ & $\begin{array}{c}-18.571^{* *} \\
(7.071)\end{array}$ & $\begin{array}{c}-15.694^{* * * *} \\
(5.579)\end{array}$ & $\begin{array}{c}-12.473 * \\
(7.083)\end{array}$ & $\begin{array}{l}-20.454 \\
(18.305)\end{array}$ & $\begin{array}{c}9.757 \\
(21.913)\end{array}$ & $\begin{array}{c}-19.108 \\
(14.764)\end{array}$ & $\begin{array}{c}-4.095 \\
(18.128)\end{array}$ \\
\hline Observations & 74 & 61 & 74 & 61 & 74 & 61 & 74 & 59 \\
\hline $\begin{array}{l}\text { Adjusted } R^{2} \\
\log \text { likelihood }\end{array}$ & $\begin{array}{r}0.355 \\
-170.5\end{array}$ & $\begin{array}{r}0.341 \\
-143.5\end{array}$ & $\begin{array}{c}0.347 \\
-169.4\end{array}$ & $\begin{array}{r}0.344 \\
-141.8\end{array}$ & $\begin{array}{c}0.352 \\
-165.0\end{array}$ & $\begin{array}{r}0.365 \\
-136.6\end{array}$ & $\begin{array}{c}0.402 \\
.\end{array}$ & $\begin{array}{c}0.426 \\
.\end{array}$ \\
\hline
\end{tabular}

Note: The table reports gravity estimates for US foreign bond holdings in 2010 (as in Eq. (1)). Estimates for the full sample and excluding offshore financial centres are obtained using simple OLS (columns 1 to 4), OLS and regional effects (columns 5 and 6) as well as robust-to-outlier (columns 7 and 8) estimation. The regional effects aim to capture unobserved investment destination effects, as suggested in Okawa and van Wincoop (2012). Our eight regions (Asia, Central America, Europe, North America, South America, Oceania; West Indies; Africa is the base region) follow the classification of US Treasury (1947). Bilateral trade with the US is instrumented with transport costs, its square as well as the number of landlocked countries in the country pair as in Aviat and Coeurdacier (2007). Robust-to-heteroskedasticity standard errors are reported in parentheses; ${ }^{* * *} p<0.01$, ** $p<0.05, * p<0.1$. 
Table 2: Gravity estimates - US foreign bond holdings in 1943

\begin{tabular}{|c|c|c|c|c|c|c|c|c|}
\hline & $\begin{array}{c}(1) \\
\text { Full } \\
\text { sample }\end{array}$ & $\begin{array}{c}(2) \\
\text { Excl. } \\
\text { offshore } \\
\text { centres }\end{array}$ & $\begin{array}{c}\text { (3) } \\
\text { Full } \\
\text { sample }\end{array}$ & $\begin{array}{c}\text { (4) } \\
\text { Excl. } \\
\text { offshore } \\
\text { centres }\end{array}$ & $\begin{array}{c}\text { (5) } \\
\text { Full } \\
\text { sample }\end{array}$ & $\begin{array}{c}\text { (6) } \\
\text { Excl. } \\
\text { offshore } \\
\text { centres }\end{array}$ & $\begin{array}{c}(7) \\
\text { Full } \\
\text { sample }\end{array}$ & $\begin{array}{c}\text { (8) } \\
\text { Excl. } \\
\text { offshore } \\
\text { centres } \\
\end{array}$ \\
\hline Log (distance from US) & $\begin{array}{l}-0.678^{*} \\
(0.356)\end{array}$ & $\begin{array}{c}-0.813^{* *} \\
(0.403)\end{array}$ & $\begin{array}{l}-0.725^{*} \\
(0.426)\end{array}$ & $\begin{array}{l}-0.849^{*} \\
(0.478)\end{array}$ & $\begin{array}{l}1.050 \\
(0.738)\end{array}$ & $\begin{array}{c}0.918 \\
(1.043)\end{array}$ & $\begin{array}{c}0.977 \\
(0.733)\end{array}$ & $\begin{array}{c}0.367 \\
(0.697)\end{array}$ \\
\hline GDP size & $\begin{array}{c}0.271^{* * * *} \\
(0.082)\end{array}$ & $\begin{array}{c}0.239 * * * \\
(0.083)\end{array}$ & $\begin{array}{c}0.271^{* * *} \\
(0.083)\end{array}$ & $\begin{array}{c}0.229 * * * \\
(0.085)\end{array}$ & $\begin{array}{c}0.271^{* * *} \\
(0.068)\end{array}$ & $\begin{array}{c}0.242^{* * * *} \\
(0.070)\end{array}$ & $\begin{array}{c}0.264 * * * \\
(0.063)\end{array}$ & $\begin{array}{c}0.190^{* * *} \\
(0.054)\end{array}$ \\
\hline Log (trade with US) & $\begin{array}{c}0.227 \\
(0.188)\end{array}$ & $\begin{array}{l}0.362 * \\
(0.213)\end{array}$ & $\begin{array}{c}0.188 \\
(0.148)\end{array}$ & $\begin{array}{l}0.344^{*} \\
(0.185)\end{array}$ & $\begin{array}{c}0.498 * * * \\
(0.173)\end{array}$ & $\begin{array}{c}0.599 * * * \\
(0.212)\end{array}$ & $\begin{array}{l}0.536^{* *} \\
(0.207)\end{array}$ & $\begin{array}{c}0.733^{* * *} \\
(0.181)\end{array}$ \\
\hline Common language dummy & & & $\begin{array}{l}-0.544 \\
(0.412)\end{array}$ & $\begin{array}{c}0.217 \\
(0.696)\end{array}$ & $\begin{array}{c}-0.638^{* *} \\
(0.309)\end{array}$ & $\begin{array}{l}-0.370 \\
(0.707)\end{array}$ & $\begin{array}{l}-0.590 \\
(0.445)\end{array}$ & $\begin{array}{c}0.561 \\
(0.523)\end{array}$ \\
\hline Cuba-Philippines dummy & & & $\begin{array}{c}1.741^{* * *} \\
(0.520)\end{array}$ & $\begin{array}{c}0.985 \\
(0.621)\end{array}$ & $\begin{array}{c}3.091^{* * * *} \\
(0.286)\end{array}$ & $\begin{array}{c}3.045^{* * *} \\
(0.630)\end{array}$ & $\begin{array}{c}3.140 * * * \\
(0.837)\end{array}$ & $\begin{array}{c}3.011^{* * *} \\
(1.097)\end{array}$ \\
\hline Common legal origin dummy & & & $\begin{array}{c}0.788 \\
(0.683)\end{array}$ & $\begin{array}{c}0.437 \\
(0.802)\end{array}$ & $\begin{array}{c}0.308 \\
(0.379)\end{array}$ & $\begin{array}{c}0.262 \\
(0.657)\end{array}$ & $\begin{array}{c}0.371 \\
(0.542)\end{array}$ & $\begin{array}{l}-0.164 \\
(0.564)\end{array}$ \\
\hline Regional effects & NO & NO & NO & NO & YES & YES & YES & YES \\
\hline Constant & $\begin{array}{c}4.493 \\
(3.005)\end{array}$ & $\begin{array}{c}4.444 \\
(3.580)\end{array}$ & $\begin{array}{c}5.225 \\
(3.453)\end{array}$ & $\begin{array}{c}4.816 \\
(4.121)\end{array}$ & $\begin{array}{c}-12.966 * \\
(6.947)\end{array}$ & $\begin{array}{l}-12.755 \\
(9.956)\end{array}$ & $\begin{array}{c}-12.728^{*} \\
(7.158)\end{array}$ & $\begin{array}{l}-9.337 \\
(6.827)\end{array}$ \\
\hline Observations & 79 & 67 & 79 & 67 & 79 & 67 & 78 & 66 \\
\hline $\begin{array}{l}\text { Adjusted } R^{2} \\
\log \text { likelihood }\end{array}$ & $\begin{array}{l}0.206 \\
-129.7\end{array}$ & $\begin{array}{l}0.250 \\
-110.2\end{array}$ & $\begin{array}{c}0.220 \\
-127.4\end{array}$ & $\begin{array}{c}0.243 \\
-108.9\end{array}$ & $\begin{array}{c}0.576 \\
-99.26\end{array}$ & $\begin{array}{r}0.559 \\
-86.65\end{array}$ & 0.416 & 0.667 \\
\hline
\end{tabular}

Note: The table reports gravity estimates for US foreign bond holdings in 1943 (as in Eq. (1)). Estimates for the full sample and excluding offshore financial centres are obtained using simple OLS (columns 1 to 4), OLS and regional effects (columns 5 and 6) as well as robust-to-outlier (columns 7 and 8) estimation. The regional effects aim to capture unobserved investment destination effects, as suggested in Okawa and van Wincoop (2012). Our eight regions (Asia, Central America, Europe, North America, South America, Oceania; West Indies; Africa is the base region) follow the classification of US Treasury (1947). Bilateral trade with the US is instrumented with transport costs, its square as well as the number of landlocked countries in the country pair as in Aviat and Coeurdacier (2007). Robust-to-heteroskedasticity standard errors are reported in parentheses; $* * * p<0.01$, ** $p<0.05, * p<0.1$. 
Table 3: Testing for a "history effect" - Baseline

\begin{tabular}{|c|c|c|c|c|c|c|c|c|}
\hline & $\begin{array}{c}(1) \\
\text { Full } \\
\text { sample }\end{array}$ & $\begin{array}{c}(2) \\
\text { Excl. } \\
\text { offshore } \\
\text { centres } \\
\end{array}$ & $\begin{array}{c}\text { (3) } \\
\text { Full } \\
\text { sample }\end{array}$ & $\begin{array}{c}\text { (4) } \\
\text { Excl. } \\
\text { offshore } \\
\text { centres } \\
\end{array}$ & $\begin{array}{c}\text { (5) } \\
\text { Full } \\
\text { sample }\end{array}$ & $\begin{array}{c}\text { (6) } \\
\text { Excl. } \\
\text { offshore } \\
\text { centres } \\
\end{array}$ & $\begin{array}{c}\text { (7) } \\
\text { Full } \\
\text { sample }\end{array}$ & $\begin{array}{c}\text { (8) } \\
\text { Excl. } \\
\text { offshore } \\
\text { centres } \\
\end{array}$ \\
\hline Log (distance from US) & $\begin{array}{c}1.510^{* * * *} \\
(0.559)\end{array}$ & $\begin{array}{c}1.931^{* * *} \\
(0.686)\end{array}$ & $\begin{array}{c}1.531^{* * *} \\
(0.475)\end{array}$ & $\begin{array}{l}1.375^{* *} \\
(0.566)\end{array}$ & $\begin{array}{l}-0.338 \\
(1.897)\end{array}$ & $\begin{array}{c}-3.901^{* *} \\
(1.894)\end{array}$ & $\begin{array}{l}-1.369 \\
(1.251)\end{array}$ & $\begin{array}{l}-2.119 \\
(1.416)\end{array}$ \\
\hline GDP size & $\begin{array}{l}-0.037 \\
(0.097)\end{array}$ & $\begin{array}{l}-0.003 \\
(0.108)\end{array}$ & $\begin{array}{l}-0.057 \\
(0.093)\end{array}$ & $\begin{array}{c}0.014 \\
(0.105)\end{array}$ & $\begin{array}{l}-0.073 \\
(0.111)\end{array}$ & $\begin{array}{c}0.000 \\
(0.136)\end{array}$ & $\begin{array}{l}-0.094 \\
(0.116)\end{array}$ & $\begin{array}{l}-0.065 \\
(0.113)\end{array}$ \\
\hline Log (trade with US) & $\begin{array}{c}1.331 * * * \\
(0.262)\end{array}$ & $\begin{array}{c}1.121^{* * *} \\
(0.280)\end{array}$ & $\begin{array}{c}1.329 * * * \\
(0.265)\end{array}$ & $\begin{array}{c}0.964 * * * \\
(0.274)\end{array}$ & $\begin{array}{c}1.229 * * * \\
(0.329)\end{array}$ & $\begin{array}{l}0.567^{*} \\
(0.296)\end{array}$ & $\begin{array}{c}1.052^{* * *} \\
(0.281)\end{array}$ & $\begin{array}{l}0.760^{* *} \\
(0.301)\end{array}$ \\
\hline 1943 bond holdings & $\begin{array}{c}0.845^{* * * *} \\
(0.185)\end{array}$ & $\begin{array}{c}1.012^{* * *} \\
(0.185)\end{array}$ & $\begin{array}{c}0.948 * * * \\
(0.178)\end{array}$ & $\begin{array}{c}1.090^{* * * *} \\
(0.186)\end{array}$ & $\begin{array}{c}1.232 * * * \\
(0.282)\end{array}$ & $\begin{array}{c}1.471^{* * *} \\
(0.266)\end{array}$ & $\begin{array}{c}1.063^{* * *} \\
(0.207)\end{array}$ & $\begin{array}{c}1.069 * * * \\
(0.207)\end{array}$ \\
\hline Common language dummy & & & $\begin{array}{c}0.694 \\
(1.171)\end{array}$ & $\begin{array}{l}-1.051 \\
(1.808)\end{array}$ & $\begin{array}{c}1.080 \\
(1.205)\end{array}$ & $\begin{array}{l}-1.370 \\
(1.559)\end{array}$ & $\begin{array}{l}1.352^{*} \\
(0.745)\end{array}$ & $\begin{array}{c}0.930 \\
(1.005)\end{array}$ \\
\hline Cuba-Philippines dummy & & & $\begin{array}{c}-4.190 * * * \\
(1.459)\end{array}$ & $\begin{array}{c}-6.334 * * * \\
(0.835)\end{array}$ & $\begin{array}{c}-4.977 * * \\
(2.124)\end{array}$ & $\begin{array}{c}-9.246 * * * \\
(1.253)\end{array}$ & $\begin{array}{c}-3.971^{* *} \\
(1.565)\end{array}$ & $\begin{array}{c}-11.742^{* * *} \\
(2.809)\end{array}$ \\
\hline Common legal origin dummy & & & $\begin{array}{c}-0.880 \\
(1.179)\end{array}$ & $\begin{array}{c}0.902 \\
(1.742)\end{array}$ & $\begin{array}{l}-0.628 \\
(1.232)\end{array}$ & $\begin{array}{c}1.798 \\
(1.516)\end{array}$ & $\begin{array}{l}-0.474 \\
(0.895)\end{array}$ & $\begin{array}{c}0.304 \\
(1.112)\end{array}$ \\
\hline Regional effects & NO & NO & NO & NO & YES & YES & YES & YES \\
\hline Constant & $\begin{array}{c}-17.848^{* * *} \\
(5.510)\end{array}$ & $\begin{array}{c}-20.049^{* * * *} \\
(6.765)\end{array}$ & $\begin{array}{c}{ }^{*}-18.029 * * * \\
(4.817)\end{array}$ & $\begin{array}{c}-14.018^{* *} \\
(5.490)\end{array}$ & $\begin{array}{c}-1.114 \\
(17.375)\end{array}$ & $\begin{array}{c}35.114 * * \\
(16.865)\end{array}$ & $\begin{array}{c}9.362 \\
(11.846)\end{array}$ & $\begin{array}{c}18.196 \\
(13.472)\end{array}$ \\
\hline Observations & 73 & 61 & 73 & 61 & 73 & 61 & 73 & 59 \\
\hline $\begin{array}{l}\text { Adjusted } R^{2} \\
\text { log likelihood }\end{array}$ & $\begin{array}{r}0.483 \\
-159.8\end{array}$ & $\begin{array}{r}0.513 \\
-133.8\end{array}$ & $\begin{array}{r}0.508 \\
-156.3\end{array}$ & $\begin{array}{r}0.551 \\
-129.7\end{array}$ & $\begin{array}{c}0.511 \\
-152.0\end{array}$ & $\begin{array}{c}0.605 \\
-121.4\end{array}$ & $\begin{array}{c}0.609 \\
.\end{array}$ & $\begin{array}{c}0.658 \\
.\end{array}$ \\
\hline
\end{tabular}

Note: The table reports gravity estimates for US foreign bond holdings in 2010 augmented with the lag of these holdings in 1943. The estimates for the full sample and excluding offshore financial centres are obtained using simple OLS (columns 1 to 4), OLS and regional effects (columns 5 and 6) as well as robust-to-outlier (columns 7 and 8) estimation. The regional effects are as in Table 1 and 2 and bilateral trade is still instrumented as explained in the notes to these tables. Robust-to-heteroskedasticity standard errors are reported in parentheses; ${ }^{* * *} p<0.01$, ** $p<0.05, * p<0.1$. 
Table 4: Testing for a "history effect" - Endogeneity

\begin{tabular}{|c|c|c|c|c|c|c|}
\hline & $\begin{array}{c}(1) \\
\text { Full sample }\end{array}$ & $\begin{array}{c}(2) \\
\text { Excl. } \\
\text { offshore } \\
\text { centres }\end{array}$ & $\begin{array}{c}\text { (3) } \\
\text { Full sample }\end{array}$ & $\begin{array}{c}\text { (4) } \\
\text { Excl. } \\
\text { offshore } \\
\text { centres }\end{array}$ & $\begin{array}{c}\text { (5) } \\
\text { Full sample }\end{array}$ & $\begin{array}{c}\text { (6) } \\
\text { Excl. } \\
\text { offshore } \\
\text { centres }\end{array}$ \\
\hline Log (distance from US) & $\begin{array}{l}1.020^{* *} \\
(0.429)\end{array}$ & $\begin{array}{l}1.093^{* *} \\
(0.486)\end{array}$ & $\begin{array}{l}-0.064 \\
(0.871)\end{array}$ & $\begin{array}{c}-0.153 \\
(0.985)\end{array}$ & $\begin{array}{c}-1.921 \\
(1.357)\end{array}$ & $\begin{array}{c}-4.149 * * \\
(2.088)\end{array}$ \\
\hline GDP size & $\begin{array}{c}0.357 \\
(0.261)\end{array}$ & $\begin{array}{c}0.414 \\
(0.283)\end{array}$ & $\begin{array}{c}0.512 * * * \\
(0.163)\end{array}$ & $\begin{array}{c}0.571^{* * * *} \\
(0.197)\end{array}$ & $\begin{array}{c}0.489 \\
(0.408)\end{array}$ & $\begin{array}{c}0.676 \\
(0.559)\end{array}$ \\
\hline Log (trade with US) & $\begin{array}{c}1.026 * * * \\
(0.380)\end{array}$ & $\begin{array}{l}0.949 * * \\
(0.418)\end{array}$ & $\begin{array}{c}0.488 \\
(0.415)\end{array}$ & $\begin{array}{c}0.449 \\
(0.420)\end{array}$ & $\begin{array}{c}0.471 \\
(0.460)\end{array}$ & $\begin{array}{l}0.150 \\
(0.497)\end{array}$ \\
\hline 1943 bond holdings & $\begin{array}{c}0.666^{* * * *} \\
(0.221)\end{array}$ & $\begin{array}{c}0.696 * * * \\
(0.233)\end{array}$ & $\begin{array}{l}0.830 * * \\
(0.355)\end{array}$ & $\begin{array}{c}0.943 * * * \\
(0.353)\end{array}$ & $\begin{array}{c}1.428 * * * \\
(0.528)\end{array}$ & $\begin{array}{c}1.626 * * * \\
(0.567)\end{array}$ \\
\hline Common language dummy & & & $\begin{array}{l}1.565^{* *} \\
(0.713)\end{array}$ & $\begin{array}{c}1.117 \\
(1.065)\end{array}$ & $\begin{array}{c}2.600 * * * \\
(0.865)\end{array}$ & $\begin{array}{c}1.881 \\
(1.300)\end{array}$ \\
\hline Cuba-Philippines dummy & & & $\begin{array}{c}-0.421 \\
(1.162)\end{array}$ & & $\begin{array}{l}-0.269 \\
(2.821)\end{array}$ & \\
\hline Regional effects & NO & NO & NO & NO & YES & YES \\
\hline Constant & $\begin{array}{c}-10.746^{* *} \\
(4.977)\end{array}$ & $\begin{array}{l}-10.850^{*} \\
(5.928)\end{array}$ & $\begin{array}{l}1.536 \\
(8.474)\end{array}$ & $\begin{array}{c}2.184 \\
(9.458)\end{array}$ & $\begin{array}{c}16.672 \\
(14.297)\end{array}$ & $\begin{array}{l}39.881^{*} \\
(21.085)\end{array}$ \\
\hline Observations & 31 & 26 & 31 & 26 & 31 & 26 \\
\hline $\begin{array}{l}\text { Adjusted } R^{2} \\
\text { 1st-stage } F \text {-statistic }\end{array}$ & $\begin{array}{c}0.465 \\
3.39 * *\end{array}$ & $\begin{array}{c}0.447 \\
13.90^{* * *}\end{array}$ & $\begin{array}{c}0.473 \\
2.65^{* *}\end{array}$ & $\begin{array}{c}0.441 \\
3.79^{* *}\end{array}$ & $\begin{array}{c}0.422 \\
1.31\end{array}$ & $\begin{array}{l}0.351 \\
2.42 *\end{array}$ \\
\hline Sargan's $\chi^{2}$ statistic & 6.71 & 4.46 & 4.08 & 4.07 & 4.79 & 4.52 \\
\hline
\end{tabular}

Note: The table reports gravity estimates for US foreign bond holdings in 2010 augmented with the lag of these holdings in 1943 instrumented with 1930s currency blocs, capital controls, protectionism and sovereign default dummies. The estimates for the full sample and excluding offshore financial centres are obtained using simple OLS (columns 1 to 4 ) as well as OLS and regional effects (columns 5 and 6). Bilateral trade is still instrumented as explained in Tables 1 and 2. The common legal origin dummy dropped out because of multicollinearity. Robust-to-heteroskedasticity standard errors are reported in parentheses; ${ }^{* * *} p<0.01,{ }^{* *} p<0.05,{ }^{*} p<0.1$. 
Table 5: Testing for a "history effect" - Other types of securities (US foreign equity holdings)

\begin{tabular}{|c|c|c|c|c|c|c|c|c|}
\hline & $\begin{array}{c}(1) \\
\text { Full } \\
\text { sample }\end{array}$ & $\begin{array}{c}\text { (2) } \\
\text { Excl. } \\
\text { offshore } \\
\text { centres }\end{array}$ & $\begin{array}{c}\text { (3) } \\
\text { Full } \\
\text { sample }\end{array}$ & $\begin{array}{c}\text { (4) } \\
\text { Excl. } \\
\text { offshore } \\
\text { centres }\end{array}$ & $\begin{array}{c}(5) \\
\text { Full } \\
\text { sample }\end{array}$ & $\begin{array}{c}(6) \\
\text { Excl. } \\
\text { offshore } \\
\text { centres }\end{array}$ & $\begin{array}{c}\text { (7) } \\
\text { Full } \\
\text { sample }\end{array}$ & $\begin{array}{c}\text { (8) } \\
\text { Excl. } \\
\text { offshore } \\
\text { centres }\end{array}$ \\
\hline Log (distance from US) & $\begin{array}{c}2.922 * * * \\
(0.722)\end{array}$ & $\begin{array}{c}3.518^{* * *} \\
(0.893)\end{array}$ & $\begin{array}{c}2.784^{* * *} \\
(0.829)\end{array}$ & $\begin{array}{l}3.033^{* *} \\
(1.161)\end{array}$ & $\begin{array}{l}1.869 \\
(2.358)\end{array}$ & $\begin{array}{c}0.712 \\
(2.882)\end{array}$ & $\begin{array}{c}2.249 \\
(2.009)\end{array}$ & $\begin{array}{c}2.334 \\
(2.385)\end{array}$ \\
\hline GDP size & $\begin{array}{l}0.198^{*} \\
(0.108)\end{array}$ & $\begin{array}{l}0.268 * * \\
(0.125)\end{array}$ & $\begin{array}{l}0.208^{*} \\
(0.109)\end{array}$ & $\begin{array}{l}0.290 * * \\
(0.135)\end{array}$ & $\begin{array}{l}0.314^{*} \\
(0.159)\end{array}$ & $\begin{array}{l}0.444^{* *} \\
(0.218)\end{array}$ & $\begin{array}{c}0.141 \\
(0.185)\end{array}$ & $\begin{array}{c}0.221 \\
(0.187)\end{array}$ \\
\hline Log (trade with US) & $\begin{array}{c}1.364 * * * \\
(0.365)\end{array}$ & $\begin{array}{l}0.967^{* *} \\
(0.430)\end{array}$ & $\begin{array}{c}1.228 * * * \\
(0.393)\end{array}$ & $\begin{array}{l}0.831^{*} \\
(0.477)\end{array}$ & $\begin{array}{c}1.280^{* * *} \\
(0.374)\end{array}$ & $\begin{array}{c}1.267^{* * *} \\
(0.438)\end{array}$ & $\begin{array}{c}1.306^{* * *} \\
(0.479)\end{array}$ & $\begin{array}{l}1.228^{* *} \\
(0.541)\end{array}$ \\
\hline 1943 equity holdings & $\begin{array}{c}1.178 * * * \\
(0.228)\end{array}$ & $\begin{array}{c}1.404 * * * \\
(0.218)\end{array}$ & $\begin{array}{c}1.294 * * * \\
(0.234)\end{array}$ & $\begin{array}{c}1.436 * * * \\
(0.216)\end{array}$ & $\begin{array}{c}1.155^{* * *} \\
(0.345)\end{array}$ & $\begin{array}{c}0.949 * * \\
(0.364)\end{array}$ & $\begin{array}{c}1.266 * * * \\
(0.339)\end{array}$ & $\begin{array}{c}1.159^{* * *} \\
(0.373)\end{array}$ \\
\hline Common language dummy & & & $\begin{array}{c}1.231 \\
(1.180)\end{array}$ & $\begin{array}{c}-2.461^{* * *} \\
(0.680)\end{array}$ & $\begin{array}{c}1.381 \\
(1.224)\end{array}$ & $\begin{array}{c}-3.285^{* *} \\
(1.364)\end{array}$ & $\begin{array}{c}1.085 \\
(1.174)\end{array}$ & $\begin{array}{l}-2.279 \\
(2.016)\end{array}$ \\
\hline Cuba-Philippines dummy & & & $\begin{array}{c}-3.921 * * * \\
(0.760)\end{array}$ & $\begin{array}{c}-3.208 * * \\
(1.373)\end{array}$ & $\begin{array}{l}-2.907 \\
(1.877)\end{array}$ & $\begin{array}{c}1.692 \\
(1.956)\end{array}$ & $\begin{array}{l}-4.714 * \\
(2.519)\end{array}$ & $\begin{array}{c}2.007 \\
(4.257)\end{array}$ \\
\hline Common legal origin dummy & & & $\begin{array}{c}-0.504 \\
(1.361)\end{array}$ & $\begin{array}{c}2.529 * * \\
(1.177)\end{array}$ & $\begin{array}{c}0.703 \\
(1.568)\end{array}$ & $\begin{array}{c}4.761^{* *} \\
(2.160)\end{array}$ & $\begin{array}{c}-0.086 \\
(1.490)\end{array}$ & $\begin{array}{c}2.599 \\
(2.194)\end{array}$ \\
\hline Regional effects & NO & NO & NO & NO & YES & YES & YES & YES \\
\hline Constant & $\begin{array}{c}-30.608^{* * *} \\
(7.005)\end{array}$ & $\begin{array}{c}-32.919 * * *- \\
(8.719)\end{array}$ & $\begin{array}{c}{ }^{4}-28.550 \text { *** } \\
(8.362)\end{array}$ & $\begin{array}{l}-27.703^{* *} \\
(11.664)\end{array}$ & $\begin{array}{c}-22.111 \\
(21.559)\end{array}$ & $\begin{array}{l}-11.532 \\
(25.963)\end{array}$ & $\begin{array}{l}-25.273 \\
(19.127)\end{array}$ & $\begin{array}{l}-25.121 \\
(22.790)\end{array}$ \\
\hline Observations & 72 & 59 & 72 & 59 & 72 & 59 & 72 & 58 \\
\hline $\begin{array}{l}\text { Adjusted } R^{2} \\
\text { log likelihood }\end{array}$ & $\begin{array}{c}0.541 \\
-175.7 \\
\end{array}$ & $\begin{array}{c}0.589 \\
-140.4\end{array}$ & $\begin{array}{r}0.548 \\
-173.5 \\
\end{array}$ & $\begin{array}{r}0.585 \\
-139.0\end{array}$ & $\begin{array}{r}0.559 \\
-168.5 \\
\end{array}$ & $\begin{array}{r}0.620 \\
-132.1 \\
\end{array}$ & 0.605 & 0.633 \\
\hline
\end{tabular}

Note: The table reports gravity estimates for US foreign equity holdings in 2010 augmented with the lag of these holdings in 1943. The estimates for the full sample and excluding offshore financial centres are obtained using simple OLS (columns 1 to 4), OLS and regional effects (columns 5 and 6) as well as robust-to-outlier (columns 7 and 8) estimation. The regional effects are as in Table 1 and 2 and bilateral trade is still instrumented as explained in the notes to these tables. Robust-to-heteroskedasticity standard errors are reported in parentheses; ${ }^{* * *} p<0.01,{ }^{* *} p<0.05,{ }^{*} p<0.1$. 
Table 6: Testing for a "history effect" - Other types of securities
(US foreign security holdings)

\begin{tabular}{|c|c|c|c|c|c|c|c|c|}
\hline & $\begin{array}{c}(1) \\
\text { Full } \\
\text { sample }\end{array}$ & $\begin{array}{c}(2) \\
\text { Excl. } \\
\text { offshore } \\
\text { centres } \\
\end{array}$ & $\begin{array}{c}\text { (3) } \\
\text { Full } \\
\text { sample }\end{array}$ & $\begin{array}{c}\text { (4) } \\
\text { Excl. } \\
\text { offshore } \\
\text { centres } \\
\end{array}$ & $\begin{array}{c}\text { (5) } \\
\text { Full } \\
\text { sample }\end{array}$ & $\begin{array}{c}\text { (6) } \\
\text { Excl. } \\
\text { offshore } \\
\text { centres } \\
\end{array}$ & $\begin{array}{c}(7) \\
\text { Full } \\
\text { sample }\end{array}$ & $\begin{array}{c}\text { (8) } \\
\text { Excl. } \\
\text { offshore } \\
\text { centres } \\
\end{array}$ \\
\hline Log (distance from US) & $\begin{array}{c}1.935^{* * * *} \\
(0.602)\end{array}$ & $\begin{array}{c}2.430 * * * \\
(0.771)\end{array}$ & $\begin{array}{c}1.844^{* * *} \\
(0.504)\end{array}$ & $\begin{array}{l}1.665^{* *} \\
(0.638)\end{array}$ & $\begin{array}{c}0.709 \\
(1.695)\end{array}$ & $\begin{array}{l}-2.523^{*} \\
(1.488)\end{array}$ & $\begin{array}{l}-1.628 \\
(1.227)\end{array}$ & $\begin{array}{c}-2.986^{* *} \\
(1.447)\end{array}$ \\
\hline GDP size & $\begin{array}{c}0.281 \\
(0.218)\end{array}$ & $\begin{array}{l}0.382^{*} \\
(0.228)\end{array}$ & $\begin{array}{c}0.216 \\
(0.229)\end{array}$ & $\begin{array}{l}0.395^{*} \\
(0.220)\end{array}$ & $\begin{array}{c}0.120 \\
(0.308)\end{array}$ & $\begin{array}{c}0.374 \\
(0.350)\end{array}$ & $\begin{array}{l}-0.216 \\
(0.201)\end{array}$ & $\begin{array}{l}-0.013 \\
(0.211)\end{array}$ \\
\hline Log (trade with US) & $\begin{array}{c}1.286 * * * \\
(0.268)\end{array}$ & $\begin{array}{c}0.970^{* * *} \\
(0.292)\end{array}$ & $\begin{array}{c}1.212 * * * \\
(0.260)\end{array}$ & $\begin{array}{c}0.766^{* * *} \\
(0.279)\end{array}$ & $\begin{array}{c}1.049 * * * \\
(0.275)\end{array}$ & $\begin{array}{c}0.421 \\
(0.265)\end{array}$ & $\begin{array}{c}0.991^{* * *} \\
(0.287)\end{array}$ & $\begin{array}{l}0.564 * \\
(0.327)\end{array}$ \\
\hline 1943 security holdings & $\begin{array}{c}0.747 * * * \\
(0.179)\end{array}$ & $\begin{array}{c}0.955^{* * *} \\
(0.173)\end{array}$ & $\begin{array}{c}0.889 * * * \\
(0.178)\end{array}$ & $\begin{array}{c}1.008 * * * \\
(0.167)\end{array}$ & $\begin{array}{c}1.118^{* * *} \\
(0.273)\end{array}$ & $\begin{array}{c}1.220 * * * \\
(0.260)\end{array}$ & $\begin{array}{c}1.248 * * * \\
(0.196)\end{array}$ & $\begin{array}{c}1.416^{* * * *} \\
(0.207)\end{array}$ \\
\hline Common language dummy & & & $\begin{array}{c}0.872 \\
(1.061)\end{array}$ & $\begin{array}{l}-1.366 \\
(1.895)\end{array}$ & $\begin{array}{c}1.175 \\
(1.037)\end{array}$ & $\begin{array}{l}-1.580 \\
(1.725)\end{array}$ & $\begin{array}{l}1.645^{* *} \\
(0.676)\end{array}$ & $\begin{array}{c}-3.441^{* * *} \\
(1.029)\end{array}$ \\
\hline Cuba-Philippines dummy & & & $\begin{array}{c}-4.833 * * * \\
(1.266)\end{array}$ & $\begin{array}{c}-6.577 * * * \\
(0.878)\end{array}$ & $\begin{array}{c}-5.583 * * * \\
(1.946)\end{array}$ & $\begin{array}{c}-8.668^{* * *} \\
(1.163)\end{array}$ & $\begin{array}{c}-5.813^{* * *} \\
(1.561)\end{array}$ & $\begin{aligned} & -8.909 * * * * \\
& (2.619)\end{aligned}$ \\
\hline Common legal origin dummy & & & $\begin{array}{c}-0.466 \\
(1.121)\end{array}$ & $\begin{array}{c}1.539 \\
(1.798)\end{array}$ & $\begin{array}{c}-0.062 \\
(1.150)\end{array}$ & $\begin{array}{c}2.165 \\
(1.732)\end{array}$ & $\begin{array}{c}-0.279 \\
(0.854)\end{array}$ & $\begin{array}{c}4.171^{* * *} \\
(1.141)\end{array}$ \\
\hline Regional effects & NO & NO & NO & NO & YES & YES & YES & YES \\
\hline Constant & $\begin{array}{c}-20.263^{* * *} \\
(6.176)\end{array}$ & $\begin{array}{c}-22.528 * * * \\
(7.783)\end{array}$ & $\begin{array}{c}-19.084^{* * *} \\
(5.261)\end{array}$ & $\begin{array}{l}-14.369 * * \\
(6.462)\end{array}$ & $\begin{array}{c}-8.417 \\
(15.489)\end{array}$ & $\begin{array}{l}24.858^{*} \\
(13.402)\end{array}$ & $\begin{array}{c}12.257 \\
(11.656)\end{array}$ & $\begin{array}{l}27.243^{*} \\
(13.843)\end{array}$ \\
\hline Observations & 71 & 59 & 71 & 59 & 71 & 59 & 71 & 59 \\
\hline $\begin{array}{l}\text { Adjusted } R^{2} \\
\log \text { likelihood }\end{array}$ & $\begin{array}{c}0.558 \\
-154.4\end{array}$ & $\begin{array}{r}0.617 \\
-125.5\end{array}$ & $\begin{array}{c}0.598 \\
-149.4\end{array}$ & $\begin{array}{c}0.660 \\
-120.3\end{array}$ & $\begin{array}{c}0.614 \\
-143.8\end{array}$ & $\begin{array}{c}0.697 \\
-112.6\end{array}$ & 0.722 & 0.785 \\
\hline
\end{tabular}

Note: The table reports gravity estimates for US foreign security (bonds and equity) holdings in 2010 augmented with the lag of these holdings in 1943. The estimates for the full sample and excluding offshore financial centres are obtained using simple OLS (columns 1 to 4), OLS and regional effects (columns 5 and 6) as well as robust-to-outlier (columns 7 and 8) estimation. The regional effects are as in Table 1 and 2 and bilateral trade is still instrumented as explained in the notes to these tables. Robust-to-heteroskedasticity standard errors are reported in parentheses; ${ }^{* * *} p<0.01, * * p<0.05$, * $p<0.1$. 
Table 7: Testing for a "history effect" - Dollar vs. non-dollar bonds

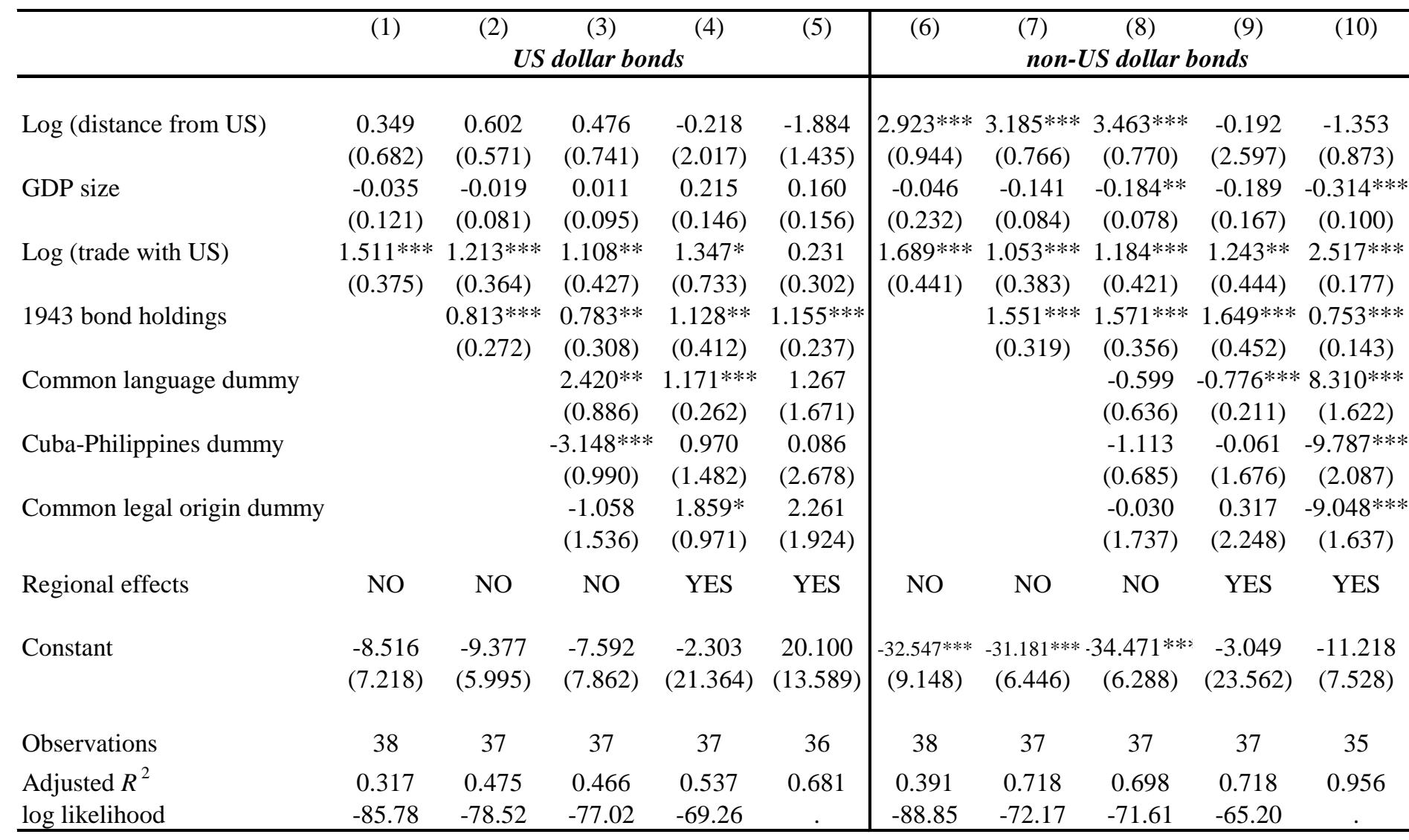

Note: The table reports gravity estimates for US foreign dollar and non-dollar holdings in 2010 augmented with the lag of these holdings in 1943 . The estimates for the full sample are obtained using simple OLS (columns 1 to 3 and 6 to 8), OLS and regional effects (columns 4 and 9) as well as robust-to-outlier (columns 5 and 10) estimation. The regional effects are as in Table 1 and 2 and bilateral trade is still instrumented as explained in the notes to these tables. Robust-to-heteroskedasticity standard errors are reported in parentheses; $* * * p<0.01, * * p<0.05, * p<0.1$. 


\section{Annex A1. Country sample}

\begin{tabular}{|c|c|c|c|c|c|c|c|c|}
\hline$\underline{\text { Africa }}$ & $\underline{\text { Asia }}$ & Central America & & rope & North America & Oceania & $\underline{\text { South America }}$ & West Indies \\
\hline Algeria & Arabia & British Honduras & Austria & Latvia & Canada & Australia & Argentina & Bahamas \\
\hline Belgian Africa & British Malaya & Costa Rica & Belgium & Liechtenstein & & New Zealand & Bolivia & Bermuda \\
\hline British East Africa & China & Guatemala & British Med. Poss. & Lithuania & & & Brazil & British West Indies \\
\hline British West Africa & French Indo-China & Honduras & Bulgaria & Luxembourg & & & British Guiana & Cuba \\
\hline Egypt & Hong Kong & Mexico & Czechoslovakia & Netherlands & & & Chile & Dominican Republic \\
\hline French Morocco & India & Nicaragua & Denmark & Norway & & & Colombia & Haiti \\
\hline French West Africa & Iran & Panama & Eire & Poland & & & Ecuador & Jamaica \\
\hline Italian Africa & Iraq & El Salvador & Estonia & Portugal & & & Paraguay & Netherlands West Indies \\
\hline Liberia & Japan & & Finland & Romania & & & Peru & \\
\hline Portuguese Africa & Netherlands East Indies & & France & Spain & & & Surinam & \\
\hline Spanish Africa & Palestine \& Transjordan & & Germany & Sweden & & & Uruguay & \\
\hline Tunisia & Philippines & & Greece & Switzerland & & & Venezuela & \\
\hline \multirow[t]{3}{*}{ Union of South Africa } & Syria & & Hungary & USSR & & & & \\
\hline & Thailand & & Iceland & UK & & & & \\
\hline & Turkey & & Italy & Yugoslavia & & & & \\
\hline
\end{tabular}

Note: The allocation of our 88 countries in the seven regional groups above follow the US Treasury (1947)'s classification. Countries in bold are those for which data on US foreign holdings of dollar-denominated bonds are available. 


\section{Annex A2. Stylised facts on US foreign bond holdings}

\begin{tabular}{lrr}
\hline \hline & $\mathbf{1 9 4 3}$ & $\mathbf{2 0 1 0}$ \\
In USD million & 2,269 & $1,604,647$ \\
As a \% of US GDP & 1.2 & 10.7 \\
As a \% of US foreign security holdings & 62.0 & 25.6 \\
\% share of dollar-denominated bonds & 68.9 & 66.1 \\
\hline \hline
\end{tabular}

Note: The table reports selected stylised facts on US foreign bond holdings in both 1943 and 2010 for the 88 countries of our sample.

\section{Annex A3. Sample adjustments}

\begin{tabular}{ll}
\hline \hline Country (1943) & Country equivalent(s) (2010) \\
\cline { 2 - 2 } Arabia & Bahrain, Kuwait, Qatar, Oman, Saudia Arabia, UAE \\
Belgian Africa & Democratic Republic of Congo \\
British East Africa & Kenya, Uganda \\
British Honduras & Belize \\
British Malaya & Singapore \\
British Mediterranean Possessions & Cyprus, Malta \\
British West Africa & Gambia, Ghana, Sierra Leone (Nigeria not included) \\
British West Indies & Anguilla, Antigua and Barbuda, Barbados, British Virgin Islands, Cayman Islands, \\
& Grenada, Jamaica, Montserrat, Saint Kitts and Nevis, Saint Lucia, Saint Vincent and the \\
Canada & Grenadines, Trinidad and Tobago and Turks and Caicos Islands \\
Czechoslovakia & Canada (including Newfoundland) \\
French Indo-China & Czech Republic and Slovakia \\
French Morocco & Vietnam, Cambodia and Laos \\
French West Africa & Morroco (including Tangiers) \\
Italian Africa & Benin, Burkina Faso, Côte d'Ivoire, Mali, Mauritania, Niger and Senegal \\
Palestine and Transjordan & Somalia and Erritrea (Libya and Ethiopia not included) \\
Poland & Israel, Jordan \\
Portuguese Africa & Poland (including Danzig) \\
USSR & Angola, Mozambique, Guinea-Bissau, Cape Verde and São Tomé and Príncipe \\
Yugoslavia & Russia and other CIS countries \\
\hline \hline
\end{tabular}

Note: The table reports the adjustments undertaken to account for the changes in country names and borders between 1943 and 2010 in the 88 countries of our sample. 